\title{
Acquisitions as Lotteries: Do Managerial Gambling Attitudes Influence Takeover Decisions?
}

\author{
Christoph Schneider and Oliver Spalt*
}

April 12, 2011

\begin{abstract}
This paper analyzes takeover announcements for public US targets from 1987 to 2008. Consistent with the hypothesis that gambling attitudes matter for takeover decisions, both acquiror announcement returns and expected synergies are lower in acquisitions where the target's stock has characteristics similar to those of attractive gambles. Offer price premium and target announcement returns are higher in these deals. The effects are stronger in companies where managers are more entrenched, where the disciplining force of product market competition is lower, where recent acquiror performance has been poor, during economic downturns, for younger CEOs in the acquiring firm, and for acquirors headquartered in areas in which local gambling propensity is higher. Targets with lottery features are more likely to be taken over and direct evidence from hand-collected synergy disclosure data shows that the market reacts less favorably to higher synergy forecasts if they are issued in the context of a lottery acquisition. Overall, our results suggest that corporate acquisitions are influenced by managerial gambling attitudes and that value destruction for acquirors in gambling-related transactions is substantial.
\end{abstract}

JEL Classification: G34, G14, G39

Keywords: Mergers and Acquisitions, Gambling, Managerial Biases.

\footnotetext{
${ }^{*}$ Christoph Schneider is at the University of Mannheim and can be reached at +49 621-181-1949 or schneider@uni-mannheim.de. Oliver Spalt is at Tilburg University and can be reached at +31 13-466-3545 or o.g.spalt@uvt.nl. We would like to thank Malcolm Baker, Nick Barberis, Gennaro Bernile, Marco Da Rin, Gang Dong, Joost Driessen, Fabio Feriozzi, Rik Frehen, Cam Harvey, Knut Heen, Byoung-Hyoun Hwang, Frank de Jong, Matti Kelohariju, Alok Kumar, Ernst Maug, Steven Ongena, Jeremy Page, Paul Sengmueller, and seminar participants at the Aalto School of Management, the University of Mannheim, the University of Maastricht, the University of Luxembourg, Tilburg University, the 2010 CEPR Gerzensee meeting, the 2010 German Finance Association meeting, the 2010 Miami Behavioral Finance conference, and the 2010 TR/SFB 15 conference for helpful discussions and valuable comments. We especially thank Gennaro Bernile for sharing the synergy forecast data. We are responsible for all remaining errors and omissions. Christoph Schneider gratefully acknowledges financial support of the collaborative research center TR/SFB 15 "Governance and the Efficiency of Economic Systems" at the University of Mannheim.
} 
"How is it that such [value destroying] deals come together in the first place? In each case, managers were clearly swinging for the fences, pouring huge sums into the bet like a Vegas gambler desperate to score a big win as he sees his chips dwindle."

From: "When Big Deals Go Bad And Why", Businessweek, 2007

\section{Introduction}

One of the central stylized facts in the literature on mergers and acquisitions, is that takeovers of public targets are on average not profitable for shareholders of the acquiring firm (Andrade, Mitchell, and Stafford (2001)). In some cases, wealth destruction for acquiring-firm shareholders is massive, and prior research has been successful in uncovering several patterns associated with particularly large losses (e.g., Moeller, Schlingemann, and Stulz (2004), Malmendier and Tate (2008), Baker, Pan, and Wurgler (2009)). Many studies suggest a close link between acquisition profitability and biases of top decision-makers, most notably CEOs, who tend to dominate large-scale M\&A decisions (e.g., Graham, Harvey, and Puri (2010)) 1

This paper shows that managerial gambling attitudes are a novel, and particularly important, driver of wealth destruction for acquiring-firm shareholders. Our central finding is that acquiror announcement returns and synergies are lower, and the offer price premium and target announcement returns are higher in "lottery acquisitions", which we define as takeover bids involving targets that look attractive as a gamble. $2^{2}$ This is consistent with gambling-prone CEOs paying a premium for the upside potential in target companies, and we present a battery of tests to establish this new gambling channel. Economically, the effects are substantial. A one standard deviation change in our main gambling variable lowers acquiror returns in lottery acquisitions in the three days around the announcement by 85bp, which amounts to $\$ 72.1$ million for the average deal, or $\$ 325$ billion across all 4,502 completed deals in our sample from 1987 to 2008 $!^{3}$ This is similar in magnitude, if not larger, than other first-order effects, including the reference point effect of Baker, Pan, and Wurgler

\footnotetext{
${ }^{1}$ The idea that managerial preferences are important for understanding takeovers in general is wellestablished, going back at least to the seminal contribution of Roll (1986), who concludes that: "takeovers reflect individual decisions."

${ }^{2}$ We use the term "lottery acquisition" without implying that these deals have the same extreme properties (in particular skewness and payoff levels) as actual lottery tickets. See also the discussion in Section 2.

${ }^{3}$ This estimate is based on a one standard deviation change in our main gambling variable, LIDX, in our baseline regression in Table V, Panel A, as calculated in Section 4.
} 
(2009), the overconfidence effect of Malmendier and Tate (2008), and the size effect documented by Moeller, Schlingemann, and Stulz (2004). More broadly, this paper documents that managerial gambling attitudes influence takeover decisions.

Gambling is pervasive in society and a preference for positively skewed lotteries that offer a large price with small probability is one of the most well-documented findings about individual decision making (e.g., Friedman and Savage (1948), Kahneman and Tversky (1979)). Such "gambling preferences" are consistent with several established theories including a preference for skewness (e.g., Mitton and Vorkink (2007)), overweighting of small probabilities of large gains as in cumulative prospect theory (Tversky and Kahneman (1992), Barberis and Huang (2008)), or rational probability distortion to account for anticipation utility (Brunnermeier and Parker (2005), Brunnermeier, Gollier, and Parker (2007)) $4^{4}$ While the impact of gambling attitudes on financial decision making has received considerable interest in the recent asset pricing literature, little research exists on the impact of gambling attitudes on corporate decision making.5 Our paper fills this gap by looking at takeovers, which are among the most significant investment decisions for companies.

Our central conjecture is that CEOs of the acquiring firm have a preference for targets that offer significant upside potential, which is consistent with the well-documented preference for long-shot gambles in individual decision-making. We therefore hypothesize that CEOs who find gambling attractive pay a premium for targets that look like attractive bets. In a sufficiently efficient capital market, this would decrease announcement returns for the acquiror, and, all else equal, increase announcement returns for the target. Moreover, since biased CEOs perceive the upside potential of the target to be higher than it actually is, synergies should, on average and all else equal, be lower in deals for which gambling attitudes matter. We develop a proxy for the attractiveness of a specific target firm as a gambling

\footnotetext{
${ }^{4}$ Because it is not our aim to distinguish between the possible underlying preference theories that could give rise to a preference for long-shots we remain agnostic and collectively refer to such preferences as "gambling preferences".

${ }^{5}$ Related papers in asset pricing include Polkovnichenko (2005), Ang, Hodrick, Xing, and Zhang ((2006), (2009)), Bali, Cakici, and Whitelaw (2009), Dorn and Sengmueller (2009), Kumar (2009), Kumar, Page, and Spalt (2009), Boyer, Mitton, and Vorkink (2010), Brav, Brandt, Graham, and Kumar (2010). Other papers that suggest a role for gambling attitudes in corporate finance include Loughran and Ritter (1995), Brav and Gompers (1997), and Green and Hwang (2009), who all look at IPOs, and Kumar, Page, and Spalt (2009), who look at employee stock option plans. Our paper is different as we specifically focus on gambling attitudes of top corporate decision makers.
} 
object and show that the above predictions are strongly supported by the data. ${ }^{6}$

While our paper is purely empirical, we have in mind a model where all CEOs are potentially biased but where the degree of bias and its impact on valuations are determined by the specific context in which the CEO operates. In particular, the degree with which managerial biases can enter valuations will be influenced by the level of managerial entrenchment and the competitive environment of the firm, both of which tighten or relax constraints on managerial discretion. In addition, the propensity to gamble of the decision makers might be influenced by macroeconomic conditions, which measure the opportunity cost of gambling, the age of the CEO, and gambling norms of the local region in which the firm is located. Lastly, the propensity to gamble is likely to increase when the performance of the acquiring firm has been poor and the manager is "gambling for resurrection" (as also suggested by the opening quote). We test refinements of our main gambling hypothesis based on these conjectures and find strong confirming evidence.

Additional evidence supports the view that gambling attitudes influence takeover decisions. Wealth destruction for acquiring firm shareholders is particularly severe when the upside potential of the target is high relative to the upside potential of the acquiror, and when the takeover involves targets that can meaningfully alter the lotteryness of the combined firm. Next, we document that targets that are attractive as a bet are more likely to be taken over, which is consistent with the view that the gambling attractiveness can induce mergers that otherwise would not have been undertaken. Finally, we directly investigate hand-collected data on synergy expectations made public by the acquiror $7^{7}$ We show that, conditional on disclosure, acquiror returns are lower for a given level of forecast synergies if the acquisition is classified as a lottery deal, i.e. the market acts less favorably to a given level of synergy forecast when the deal is likely influenced by managerial gambling attitudes.

The main methodological innovation we add to the literature on takeovers is to construct an index which measures how much a target's stock resembles salient features of attractive

\footnotetext{
${ }^{6}$ We stress that we do not mean to suggest that mergers are conducted purely because CEOs want to gamble. We believe that all textbook reasons for two firms to merge are relevant (and we therefore control for a large number of firm and deal characteristics in our empirical work). What we do suggest is that, in addition to these established reasons, the gambling attractiveness of a target enters the overall assessment of the takeover opportunity by the CEO in ways that are systematic and economically important.

${ }^{7}$ We thank Gennaro Bernile for providing us with the synergy data.
} 
gambles. Specifically, the main variable we use to identify target firms as of lottery type, LIDX, is an index combining the expected idiosyncratic skewness, idiosyncratic volatility, and price features of the target's stock. This index is inspired by Kumar (2009), who constructs a similar index in his analysis of gambling behavior of retail investors. Intuitively, the motivation for using these three features is that attractive gambles are usually cheap, their payoffs are risky (i.e. have a high variance), and, most importantly, they offer a small chance of a large payoff (i.e. they have a high skewness). Theoretically, a preference for expected idiosyncratic skewness is a direct implication from the cumulative prospect theory model of Barberis and Huang (2008). High volatility will amplify the perception of skewness and the resulting speculative appeal of the stock (Baker and Wurgler (2007)) ${ }^{8}$ Lastly, although the nominal price of one share should be largely irrelevant from the viewpoint of standard theory, Weld, Benartzi, Michaely, and Thaler (2009) suggest that there exists a common perception among investors and managers of what a "normal" range for the nominal price of a stock should be. Target firms with stock prices below this norm are more likely to be perceived as cheap bets. We show that LIDX has significant incremental explanatory power for premia and announcement returns that is not captured by standard variables established in prior research.

Within the classification of Baker, Ruback, and Wurgler (2008), our paper analyzes biased managers in rational markets. The existence of biased managers is supported by prior research showing that biases are not in general less relevant for professionals (e.g. Coval and Shumway (2005), Haigh and List (2005)). Moreover, even when M\&A decisions are taken in teams and using external consultants, there is no guarantee that inflated expectations about project success are corrected in groups (Kahneman and Lovallo (1993)). Lastly, existence and impact of CEO biases on firm policies have been documented in various other settings (e.g., Malmendier and Tate (2005), Malmendier and Tate (2008), Ben-David, Graham, and Harvey (2010)).

Our main gambling conjecture is consistent with the data if the long-shot preference of

\footnotetext{
${ }^{8}$ As a practical matter, volatility and skewness are intimately linked. This can be the result from an actual functional relationship such as in the case of stock prices following a geometric Brownian motion. The link can also be due to how individuals evaluate the attractiveness of gambles. The behavioral tendency to disregard a high return from a high skewness stock as an outlier if high returns are observed only rarely, i.e. if the variance is low, suggests that both variance and skewness are important.
} 
CEOs is stronger than the bias of the underlying shareholder base. This might appear to be in contrast to a body of work that assumes that managers are more risk-averse than shareholders (e.g., Amihud and Lev (1981), Coles, Daniel, and Naveen (2006)) $!^{9}$ However, conceptually, individuals may well be both risk-averse for some decisions and risk-seeking for others, as exemplified by the simultaneous demand for insurance and lottery tickets that is documented going back at least to Friedman and Savage (1948). Consistent with this view, simultaneous risk aversion for symmetric bets and a preference for long-shot gambles have been found to co-exist within the same decision maker in numerous lab and field studies (e.g., Tversky and Kahneman (1992), Kachelmeier and Shehata (1992), Golec and Tamarkin (1998)). Ultimately, the question if the gambling propensity of CEOs is larger than that of the underlying shareholder base is an empirical one. The best direct evidence on the subject we are aware of comes from a recent study by Graham, Harvey, and Puri (2009). These authors analyze a large-scale survey among CEOs and conclude that only $9.9 \%$ of their CEOs have little risk-tolerance and that the average CEO has a much higher propensity to gamble than the lay population. They show that this willingness to take risks translates into more frequent mergers (a finding we corroborate in our much larger data set), and conjecture that there might even be a selection mechanism by which "risk-takers that succeed are the "winners" that ultimately make it to the CEO position." The assumptions we make in this paper are therefore supported by the direct evidence in Graham, Harvey, and Puri (2009).

There are several alternatives to our gambling hypothesis that we consider. (i) The overconfidence-hypothesis under which CEOs are more overconfident for targets with a lot of upside potential, and therefore overpay for them. (ii) The hard-to-value-hypothesis, according to which valuation mistakes for hard-to-value targets translate into higher offer premia. (iii) The real-options-hypothesis under which targets with a lot of upside potential are rationally valued higher because they have a higher implied option value. (iv) The managerial-payhypothesis, under which the convexity of managerial pay contracts leads managers to engage in riskier deals. We show that - in contrast to our gambling hypothesis - none of these alternatives can provide a convincing explanation for the effects we document.

\footnotetext{
${ }^{9}$ Some prior authors have proposed reputation concerns or managerial concern for job security as additional factors that can attenuate managerial propensity to take risk (e.g., Treynor and Black (1976), Hirshleifer and Thakor (1992)).
} 
Our study contributes to the literature on mergers and acquisitions by identifying an new, economically important, determinant of takeover premia, synergies, and announcement returns ${ }^{10}$ Specifically, the results in our paper suggest that managerial gambling attitudes are a significant, previously overlooked, driver of wealth destruction in corporate takeovers. Our findings also add to the literature that examines managerial objectives as a driver of bad acquisition decisions. Lang, Stulz, and Walkling (1991) find support for Jensen's (1986) free-cash flow hypothesis. Morck, Shleifer, and Vishny (1990) consider private benefits to the acquiring firm's managers more generally and find that acquiror returns are lower when managerial benefits from the transaction are likely to be high. Masulis, Wang, and Xie (2007) show that bidder returns are lower in firms with weaker corporate governance, which is consistent with managerial objectives being a driver of bad acquisitions. We extend and complement these earlier findings by suggesting that an important source of private benefits come from managerial gambling objectives and that the adverse effects on merger success are especially pronounced in poorly governed firms.

More broadly, our paper contributes to the literature that focuses on CEO characteristics and their impact on firm policies (Bertrand and Schoar (2003)) by introducing managerial gambling attitudes as a first-order determinant of top-level corporate decisions.

We develop our hypotheses in Section 2. Section 3 presents the data set used. The impact of target lottery characteristics on offer price premia, synergies, and announcement returns is analyzed in Section 4. Section 5 provides additional empirical evidence and tests some finer predictions of our gambling hypothesis. Section 6 concludes.

\section{Hypotheses}

Our main conjecture in this paper is that managerial gambling attitudes induce a preference for target firms that look like attractive gambling opportunities. We describe the testable implications from this main conjecture in this section and summarize them in Hypotheses one to ten.

Before proceeding, we stress that, while we refer to the deals in which gambling attitudes

\footnotetext{
${ }^{10}$ The literature on mergers and acquisitions is too large for us to review here. Many excellent survey articles exist including Andrade, Mitchell, and Stafford (2001) and Betton, Eckbo, and Thorburn (2008).
} 
would be important as "lottery acquisitions", there are significant differences between actual lottery tickets and the large corporate transactions we analyze. The most important difference is in the skewness of the bet (typically, lottery tickets increase the wealth of a winner by several orders of magnitude) and the price of the lottery. Importantly, nothing that we do relies on the extreme properties of actual lottery tickets. For example, Kachelmeier and Shehata (1992) show that certainty equivalents can exceed expected values already for lotteries in which the winning probability is $20 \%$. Moreover they show that gambling behavior is not exclusive to settings in which the price of the lottery is only a small fraction of wealth. Hence, while we use the term lottery acquisition to be consistent with prior related literature (e.g., Barberis and Huang (2008), Kumar (2009)), and while we hope the metaphor adequately captures the main gambling intuition, our analysis does neither rely on extremely large payoffs, nor do we mean to imply that our effects should only be relevant when the target is small relative to the acquiror.

\subsection{Baseline hypotheses}

The baseline set of hypotheses (H1 to H4) addresses the relation between lottery acquisitions and offer price premia, announcement returns, and synergies.

In a given acquisition, the offer price premium (the premium paid for the target's stock relative to its pre-announcement value) depends on both the stand-alone valuation of the target and the expected synergies from the deal. Managers with high gambling propensity will pay a premium for targets that look like attractive bets, and thus be willing, all else equal, to pay a higher premium in lottery acquisitions: ${ }^{11}$

H1 (Offer price premium): The offer price premium is higher if the target is an attractive gambling object, i.e. if the target's stock more closely resembles salient characteristics of lotteries.

Alternatively, managers might be willing to acquire a lottery type target for the same price than an otherwise identical non-lottery type target even if it has a lower expected level of

\footnotetext{
${ }^{11}$ This reasoning goes through if we assume that target managers are also biased. In this case, they are not willing to sell the firm at the true price, which will tend to exacerbate the effect that the offer price premium will be higher in lottery acquisitions. We assume that the bargaining power between bidder and target is independent of the lottery characteristics of the target, which seems like a natural first pass.
} 
synergies than the latter.

H2 (Synergies): Synergies are lower in lottery acquisitions.

Note that Hypothesis 1 is closely related to Hypothesis 2. Specifically, if synergies were significantly higher in lottery acquisitions, a higher offer price premium may not necessarily indicate a role for gambling behavior. However, if Hypotheses 1 and 2 are both borne out by the data then managers are willing to pay a higher premium in lottery acquisitions even though these acquisitions come with lower synergies. Finding this pattern in the data would thus provide strong support for our main gambling conjecture.

We assume that the market is (sufficiently) rational and that it does not assign a premium to idiosyncratic upside potential. Hence, the announcement return of the acquiror will be lower in lottery acquisitions.

H3 (ACARs): Announcement returns for the acquiror are lower in lottery acquisitions.

While the prediction for bidder announcement returns are unambiguous, note that there are two offsetting effects for target announcement returns. Target announcement returns might be higher, because, for a given level of synergies, a premium in the offer price is a pure wealth transfer to target shareholders. However, on average smaller synergies for lottery acquisitions will, all else equal, decrease target announcement returns in these deals, since the surplus that can be split between bidder and target is smaller. If target announcement returns are higher or lower in lottery acquisitions is thus an empirical question. As for the offer price premium, finding higher announcement returns for target shareholders despite lower synergies for lottery acquisitions would provide strong evidence consistent with our main gambling hypothesis.

H4 (TCARs): Announcement returns for the target are higher in lottery acquisitions.

An important feature of our identification strategy is to look at premia, synergies, and announcement returns jointly. For example, higher offer price premia in lottery acquisitions by themselves could be consistent with paying more for a real option since lottery acquisitions by definition have higher volatility. However, if both synergies and announcement returns 
are lower for lottery acquisitions (as we show below), we can reject this more traditional alternative hypothesis. More generally, any alternative to our gambling hypothesis must be consistent with the patterns we document for offer premia, synergies, and announcement returns.

\subsection{Additional evidence}

Hypotheses 5 to 10 summarize additional testable implications from our managerial gambling conjecture that further increase our power to identify an important role for gambling attitudes in takeover decisions.

We first, posit that bidder CEOs would care more about the upside of the target if this upside is not eliminated when the two firms are combined.

H5 (Lotteryness of combined firm): The gambling effects we document are stronger if the target is likely to increase the upside potential of the combined firm.

Next, we hypothesize that our effects should be more pronounced if the CEO of the bidder is ex ante more likely to find gambling attractive. We use three proxies for higher gambling propensity 12 First, we rely on a geographical proxy based on religiously-induced gambling norms proposed by Kumar, Page, and Spalt (2009). These authors show that the local culture in Catholic counties in the US is more accepting of gambling activities and that these local norms translate into financial decisions of firms an individuals in these areas. In our setting, we would expect more pronounced gambling effects for bidders located in areas where the propensity to gamble is higher. Our second proxy builds on evidence suggesting that betting on long shots becomes more attractive during economic downturns. Evidence for this has been provided in the context of state-lotteries (e.g. Brenner and Brenner (1990) and Mikesell (1994)) and in the context of retail investor behavior, who invest more in lottery type stocks in bad economic conditions (Kumar (2009)). In our context, because economic downturns put a limit on growth opportunities available through standard economic activity, gambling in acquisitions is likely to become relatively more attractive. Finally we use CEO age as a third proxy and conjecture that older CEOs would be less likely to gamble.

\footnotetext{
${ }^{12}$ See also Section 5 for additional details on these proxies.
} 
This is motivated by prior evidence that behavioral biases, and preference for skewness in investment returns in particular, tend to decrease with age (e.g., List (2003), Goetzmann and Kumar (2008), Kumar (2009)). Consistent with this evidence, studies on lottery participation generally find that younger individuals participate more and spend more money on the activity (e.g., Brenner and Brenner (1990)).

H6 (Gambling propensity): Gambling effects in lottery acquisitions should be more pronounced for (i) firms located in a region where the local population is more likely to find gambling attractive (ii) during economic downturns, and (iii) when the bidder firm CEO is younger.

Gambling propensity will be constrained by the firm environment in which the managers operate. In particular, managers who have more discretion because they are shielded from competitive forces will be more likely to make value destroying acquisitions. The first determinant of managerial discretion we use is managerial entrenchment as measured in the well-known governance index of Gompers, Ishii, and Metrick (2003). The second determinant of managerial discretion we use is CEO equity ownership. Following, Morck, Shleifer, and Vishny (1988) we conjecture that managers with very high equity stakes would be more entrenched and therefore engage more in value destroying lottery acquisitions. Finally we use product market competition (e.g. Giroud and Mueller (2010)) as a measure of managerial discretion. The fiercer the product market competition, the more costly is every dollar lost on a bad acquisition. Moreover, firms that can successfully compete in very competitive environments are more likely to have good financial checks and balances in place.

H7 (Managerial discretion): Gambling effects in lottery acquisitions should be more pronounced for firms in which the management is more entrenched and in industries where product market competition is low.

Our next hypothesis draws on the well-established fact that the willingness to gamble increases strongly if the alternative is a sure loss (e.g., Kahneman and Tversky (1979), Thaler and Johnson (1990)). We hypothesize that this "gambling for resurrection" effect is also relevant in our takeover setting. If a firm has recently underperformed (e.g. low stock returns in 
the recent past, large difference to 52-week high, or negative net income last year) managers might perceive themselves to be in the loss space, which would increase their willingness to bet on a long-shot to break even (see also the opening quote).

H8 (Gambling for resurrection): Gambling effects in lottery acquisitions should be more pronounced for firms which have recently underperformed.

Since it seems implausible that managers in firms that have recently performed badly would be more optimistic and confident in their own abilities than managers who have done well, this last hypothesis allows us to distinguish our gambling motivation from overconfidence ${ }^{13}$

Gambling attitudes might also influence takeover "styles" of acquirors. We therefore conjecture that the average deal would be more lottery-like if the gambling propensity of the $\mathrm{CEO}$ is high, if the $\mathrm{CEO}$ has a lot of discretion, and if gambling for resurrection is relevant for the bidder in the year. Similarly, if bidder CEOs put a premium on upside potential of the target, then, all else equal, lottery-type targets should be more likely to be taken over.

H9 (Takeover style and takeover probability): The average acquisition of an acquiror would look more like a lottery acquisition, if managerial gambling propensity is high, if bidder CEOs are entrenched, and if gambling for resurrection is relevant in the given year. Target firms with lottery features should be more likely to be taken over.

The second part of this hypothesis complements the evidence in Graham, Harvey, and Puri (2009) who find that CEOs with higher gambling propensity make more acquisitions.

Inflated synergy expectations are a natural way in which gambling attitudes could influence takeover decisions. We therefore hypothesize:

H10 (Synergy forecasts): Synergy forecasts would, all else equal, be larger in lottery acquisitions. The market would discount synergy forecasts issued by the bidder management in lottery acquisitions, when evaluating the overall value impact of the merger on the acquiror.

The second part of the hypothesis follows from our assumption that the market is rational.

\footnotetext{
${ }^{13}$ It would also run counter to well-known models that explain the evolution of overconfidence as resulting from learning in a self-serving attribution bias framework, as in Gervais and Odean (2001).
} 
Because, in lottery acquisitions, there is a probability that synergy forecasts issued by the bidder are inflated because of gambling attitudes, the same synergy forecast in a non-lottery deal would impact bidder returns more positively.

\section{Data}

\subsection{Construction of the dataset}

Our initial sample consists of all takeover bids involving public US targets and US acquirors listed in the Thomson Reuters SDC database from January 1, 1987 to December 31, 2008. Following Baker, Pan, and Wurgler (2009) we require that the bidder offers to purchase at least $85 \%$ of the target firm shares or that the portion of shares acquired is not reported. We exclude deals with missing offer price, deals with a deal value smaller than $\$ 1$ million, repurchases, recapitalizations, rumored, and target solicited deals. We are able to compute our lottery index, described in detail below, for 6,004 of these firms. We obtain stock price data from CRSP and balance sheet data from Compustat for both acquiror and target firms. Table I shows our final sample.

The dependent variables we use are standard. The offer price premium is reported by SDC and defined as the difference between the price per share of the target paid and the price four weeks prior to the deal announcement divided by the price 4 weeks prior to the deal announcement. We calculate acquiror and target cumulative abnormal returns over a three day window around the announcement using market model estimates based on daily data estimated over days [-280,-31]. Synergies are estimated following the procedure in Bradley, Desai, and Kim (1988) as a weighted average (by market capitalization) of target and bidder percentage returns.

The main explanatory variable we use is the lottery index LIDX, which measures how much a target stock shares salient characteristics of attractive gambles. To construct LIDX, we need measures of price, volatility, and skewness 14 We use the method of Boyer, Mitton,

\footnotetext{
${ }^{14}$ Kumar (2009) analyzes retail investors and therefore uses lagged idiosyncratic skewness instead of expected idiosyncratic skewness. While it is plausible that retail investors cannot compute the theoretically called for expected skewness, and therefore use lagged skewness as a naive predictor, we use expected skewness because we assume that the top managers we analyze are sophisticated enough to gauge the future upside potential of a target. We show in the robustness section that our main results obtain also when we use lagged instead of expected skewness.
} 
and Vorkink (2010) to estimate expected idiosyncratic skewness (EISKEW), i.e. to identify targets that have the potential to generate large future payoffs ${ }^{15}$ Boyer, Mitton, and Vorkink (2010) show that past skewness is a weak predictor of future skewness and propose a crosssectional estimation procedure instead 16 To estimate EISKEW, we first run for each month the regression

$$
i s_{i, t}=\beta_{0, t}+\beta_{1, t} i s_{i, t-T}+\lambda_{t}^{\prime} \mathbf{X}_{i, t-T}+\epsilon_{i, t}
$$

on the whole universe of CRSP firms. Here, $i s_{i, t}$ is idiosyncratic skewness of stock $i$ at the end of month $t, i s_{i, t-T}$ is idiosyncratic skewness at the end of month $t-T$, and $\mathbf{X}_{i, t-T}$ is a vector of additional firm-specific variables observable at the end of month $t-T$. Firm-specific variables include idiosyncratic volatility, momentum, turnover, and a set of dummy variables for firm size (small, medium, large), industry (based on 2-digit SIC codes), and NASDAQ stocks. In the spirit of computing expected returns in a standard event study, we then use the coefficients from this regression to estimate expected idiosyncratic skewness at the end of month $t+T$ as:

$$
E I S K E W \equiv E_{t}\left[i s_{i, t+T}\right]=\beta_{0, t}+\beta_{1, t} i s_{i, t}+\lambda_{t}^{\prime} \mathbf{X}_{i, t} .
$$

The choice of the forecast horizon $T$ is ultimately subjective. As a baseline case we use $T=48$, which implies that managers have a four year timeframe in mind when evaluating a potential acquisition target 17 Since the turnover variable for NASDAQ stocks is only reported on a widespread basis from January 1983, this procedure determines the start date of our sample period as January 1987. The second lottery feature in LIDX is idiosyncratic volatility (IVOLA), measured as the regression residual from a Fama and French (1993) three-factor model, estimated using daily data over a four year period ${ }^{18}$ We use a four year

\footnotetext{
${ }^{15}$ Although total skewness could also be attractive to individuals with high gambling propensity, we focus on idiosyncratic skewness to align our work with the predictions from the Barberis and Huang (2008) model, and to distinguish our results from the well-known effects of coskewness (e.g. Kraus and Litzenberger (1976), Harvey and Siddique (2000)). We use idiosyncratic volatility instead of total, or systematic, volatility for analogous reasons.

${ }^{16}$ See Boyer, Mitton, and Vorkink (2010) for additional details on the estimation procedure.

${ }^{17}$ In the robustness checks we show that our results are not very sensitive to this horizon and that $T$ equal to 24,36 , or 60 months produces similar results.

${ }^{18} \mathrm{We}$ obtain the Fama-French factors from Kenneth French's website: http://mba.tuck.dartmouth.edu/pages/faculty/ken.french/data_library.html.
} 
horizon to match the estimation of EISKEW. Lastly, we obtain the stock price at the end of month $t$ from CRSP.

To construct LIDX, each month we independently sort all CRSP stocks with sharecodes 10 or 11 into 20 bins for each of the lottery features (expected idiosyncratic skewness, idiosyncratic volatility, and price), such that higher bin numbers indicate greater attractiveness as a gambling object. For example, a stock with very low price, and very high skewness and volatility would be in bin 20 for price, skewness, and volatility, respectively. We then form LIDX by adding the three individual scores. Finally, we rescale LIDX such that it lies between 0 (least attractive as a gamble) to 1 (most attractive as a gamble). Having obtained a value for the lottery index, we then assign the value of LIDX at the end of month $t-2$ to a target firm with announcement date in month $t$. We use lagged values here, and in all other explanatory variables to make sure information leakage and other contemporaneous effects are not contaminating our results. We label a target with a high value of LIDX a lottery type target and we call a transaction involving a lottery type target a lottery acquisition. Table I shows that the fraction of lottery acquisitions is overall fairly stable across years.

In addition to our main variable LIDX, we control for standard variables identified in the literature in all our regressions. In particular, following Baker, Pan, and Wurgler (2009), we control for the return on assets, defined as net income (Compustat: NI) over total assets (Compustat: AT), market capitalization, defined as price (CRSP: PRC) times shares outstanding (CRSP: SHROUT), and the book to market ratio, defined as book equity divided by market capitalization, where book equity is total shareholders' equity (Compustat: SEQ) plus deferred taxes and investment tax credit (Compustat: TXDITC) minus the redemption value of preferred stock (Compustat: PSRKRV). All these variables are calculated for acquirors and targets, and are based on the last fiscal year end before the announcement. Following Moeller, Schlingemann, and Stulz (2004) we include additional control variables. First, we obtain a set of deal characteristics from SDC, including dummy variables indicating payment through stock only or cash only, tender offers, hostile takeovers, conglomerate mergers (mergers in which the bidder is in a different 2-digit SIC code industry than the target), and competed deals (with more than one bidder). We also include the relative size of bidder and target, a dummy variable indicating new economy firms (classified by SIC codes 
3570 to $3579,3661,3674,5045,5961$, or 7370 to 7379 as in Oyer and Schaefer (2004)), and the number of transactions in the same 2-digit SIC code industry and year, to control for periods of heightened M\&A activity in all our regressions. We winsorize all variables at the $1 \%$ and $99 \%$ level. We show in the robustness section that our main results do not change when we use unwinsorized data.

In some of our tests we use religious affiliation data obtained from the "Churches and Church Membership" files from the American Religion Data Archive (ARDA), county-level demographic data from the U.S. Census, the aggregate market-level sentiment index data from Jeffrey Wurgler's website, the GIM-index data from Andrew Metrick's website, the Chicago Fed national activity index (CFNAI), CEO age, compensation, and ownership data from ExecuComp, analyst forecast data from I/B/E/S and data on institutional shareholders from Thomson Reuters. We provide an overview of all variables used in our analysis and their definitions in the Appendix.

\subsection{Summary statistics}

Table II presents summary statistics for the main variables we use. We report means, medians, the standard deviation, and several percentiles of interest. We also report the number of observations for each variable, which varies due to data availability. The median offer price premium is $35.3 \%$. Median cumulative abnormal announcement returns for bidders from day -1 to day +1 is $-1.2 \%$. The median target announcement return is $16.4 \%$. Synergies, the combined change of bidder and target returns, are $1.0 \%$, so offers are on average expected to create value.

The median acquiror has a market capitalization of $\$ 1.3$ billion, a book to market ratio of 0.46 , and a return on assets of $3.1 \%$. The median target has a market capitalization of $\$ 106.0$ million. Since we are looking only at public targets, these are on average sizeable firms. For the median offer, the proposed deal value is $24 \%$ of the market capitalization of the acquiror, which illustrates that these transactions are important financial decisions for acquirors. With 0.64 , the median book to market ratio of targets is larger than the book to market ratio of acquirors. The performance of targets in terms of return on assets is $1.5 \%$ and thus consistent with the idea, that, on average, underperforming firms are more likely to become targets. $16 \%$ of targets are new economy firms. 
Looking at deal characteristics, Table II shows that $40 \%$ of the bids offer cash only, while $29 \%$ of bids offer stock only. $19 \%$ of the offers in our sample are tender offers, and $1.8 \%$ of bids are classified by SDC as hostile. For a large fraction of offers, $47 \%$, the bidder is in a different 2-digit SIC code industry as the target. Multiple bidders are present in $10 \%$ of cases and $75 \%$ of the offers in our sample lead to successfully completed deals.

\section{Empirical Results}

This section presents our main results. We largely follow the prior literature in the regressions we run and the control variables we use. Specifically, we regress the offer price premium, synergies, and announcement returns on our lottery measures, a set of acquiror and target characteristics suggested by Baker, Pan, and Wurgler (2009) and a set of deal characteristics suggested by Moeller, Schlingemann, and Stulz (2004). We also include a dummy variable indicating new economy firms (classified by SIC code as in Oyer and Schaefer (2004)), and the number of transactions in the same 2-digit SIC code industry and year, to control for periods of heightened M\&A activity. We run OLS regressions and cluster standard errors in all regressions by announcement month.

Our main lottery variable is the LIDX index, where a higher index value indicates greater attractiveness as a gamble. Although we do not expect any single measure to capture the attractiveness of a target as a gamble as well as LIDX, for completeness we present also the results for using the components of the index, expected idiosyncratic skewness, idiosyncratic volatility, and price of the target's stock prior to the announcement.

\subsection{Offer price premia}

We hypothesize that the offer price premium would be higher in lottery acquisitions (Hypothesis 1). We find strong support for this hypothesis when we regress the offer price premium on the lottery index LIDX (Table III). We also find that the individual components are related to the offer price premium as expected: higher skewness and volatility increase the offer price premium, while higher price decreases it. All coefficients are highly statistically significant. They are also economically significant. A one standard deviation change in LIDX increases the offer price premium by $16.2 \%(=0.25 \times 27.78 / 42.97)$. The average market capitalization 
of targets is $\$ 640.0$ million, so a $16.2 \%$ higher premium represents an additional $\$ 44.6$ million $(=\$ \mathrm{~m} 640 \times 16.2 \% \times 43.0 \%)$ in consideration paid to target shareholders for the average transaction. Hence, the effects we document are large.

The signs and significance of our control variables are consistent with those reported in other studies (e.g., Baker, Pan, and Wurgler (2009)). In particular, we find that larger acquirors pay more, and that offer price premia are higher in tender offers, hostile bids, and in deals with multiple bidders. Lastly, we find that offer price premia are higher for targets in new economy industries.

\subsection{Synergies}

Our second hypothesis is that on average synergies would be lower in lottery acquisitions. Again, our empirical results are consistent with this hypothesis (Table IV). Following Bradley, Desai, and Kim (1988), we measure synergies as the sum of target and acquiror three day announcement returns weighted by the market capitalizations of the target and acquiror, respectively. Table IV shows that synergies are decreasing in LIDX. A one standard deviation change in LIDX leads to synergies that are on average 60 basis points lower $(=0.25 \times 2.40)$. Relative to the mean percentage synergies of $1.55 \%$, this represents a $39 \%$ decrease. Looking at the components of LIDX, we find, as conjectured, lower synergies for high skewness and high volatility targets, and lower synergies if the target share price is low. Overall, these results provide strong support for Hypothesis 2. They also provide strong additional support to Hypothesis 1: managers are willing to pay a higher premium even though they are on average facing lower synergies in lottery acquisitions.

\subsection{Announcement returns for acquiror and target}

If lottery acquisitions have lower synergies and higher offer price premia, then we expect negative acquiror returns around the announcement date (Hypothesis 3). Table V, Panel A presents results consistent with this hypothesis. When we regress three day announcement returns for the acquiring firm on LIDX, we find that a one standard deviation increase in LIDX decreases the announcement return of the acquiror by 85 basis points $(=0.25 \times$ 3.39 ), which is $50.0 \%$ relative to the mean announcement return of $-1.69 \%$. The mean size of the acquiror in our sample is $\$ 8.48$ billion, so this would translate into an additional 
loss due to gambling attitudes of $\$ 72.1$ million $(=\$$ bn $8.48 \times 50.0 \% \times 1.69 \%)$ in acquiror firm value around the announcement due to gambling behavior. Also in this setting, the individual components of the index are significant and have the expected sign, providing further evidence to support our hypothesis that gambling attitudes influence acquisition decisions.

Because the effects of LIDX on offer price premia and synergies have opposite effects on target returns, we do not have a clear prediction for the announcement returns of target firms. For completeness, Panel B of Table V presents results for targets. Three day announcement returns are positively related to the lottery index, and its constituents, high skewness and high volatility, and negatively to the price of the target. A one standard deviation change in LIDX increases target announcement returns by $13.8 \%(=11.48 \times 0.25 / 20.74)$, or about $\$ 18.3$ million $(=\$ \mathrm{~m} 640 \times 13.8 \% \times 20.74 \%)$. This is consistent with acquirors paying a sufficient premium for targets that look like attractive gambles to compensate for the smaller gains from synergies.

\subsection{Robustness checks}

So far, our results provide strong evidence suggesting that gambling attitudes influence deal pricing in lottery acquisitions. In this section we present a battery of robustness checks for our regressions with offer price premium, synergies, and announcement returns as dependent variables. The main results from columns (5) in Tables III, IV, and V, are shown at the top of each panel as "baseline." For conciseness, we show the results for our main index, LIDX, only.

Table VI, Panel A demonstrates that our results are robust to using alternative time periods to estimate key variables. First, we vary the horizon over which we estimate the expected idiosyncratic skewness with the Boyer, Mitton, and Vorkink (2010) method. Our baseline is four years. For robustness, we show results for two, three, and five year estimation periods. Our results are essentially unaffected by the horizon we choose. Next, we vary the event window we use to calculate cumulative abnormal announcement returns. We find a consistent pattern in line with our baseline results when we use five, seven, eleven, or forty-one day windows.

In Table VI, Panel B, we run our regressions on a number of subsamples. First, we divide 
our sample into large and small acquirors since prior research suggests potential differences in the acquisition success between large and small firms (Moeller, Schlingemann, and Stulz (2004)). We also split our sample into large and small targets to investigate if our results are driven by a particular subsample of targets. As can be seen from Table VI, Panel B, the lottery acquisition effect is present in all subsamples. Next, we use the sentiment index of Baker and Wurgler (2006) to see if our regressions are picking up effects related to sentiment, i.e. market effects, rather than effects from managerial preferences. We conclude from the sentiment sample split, and the fact that our main predictions regarding the offer price premium, synergies and announcement returns are present in both subsamples, that we are picking up effects distinct from sentiment.

The lottery index is correlated with measures of financial distress (most notably through price), and we need to make sure that we are capturing distinct gambling effects, rather than distress effects. To do this, we split the sample by Z-Score (Altman (1968)). We also consider a second measure that we construct as the predicted value from the baseline specification (model 2 in Table III) of Campbell, Hilscher, and Szilagyi (2008), and call it the CHS-Score. When we measure closeness to distress by the Z-Score, our effects are somewhat stronger for the subsample closer to distress. When we use the CHS measure, we find that the effects are stronger in the subsample with a lower predicted probability of going into distress (low CHSScore). All coefficients have the correct sign and are significant at conventional levels in all four subsamples. Hence, we conclude that our lottery index captures effects that are distinct from financial distress. In our last set of results we split our sample into three subperiods. We find that our effects are stronger in the later part of the sample. They have thus become even more relevant recently, consistent with some research suggesting a growing gambling propensity in financial markets (Shiller (2000), Brav, Brandt, Graham, and Kumar (2010)).

In Table VI, Panel $\mathrm{C}$ we use alternative setups to estimate our main regressions. We first include a set of year dummies, which makes our results stronger than in the base case. Next, we include both year and industry dummies (2-digit SIC codes), and find that this does not materially affect size and significance of our coefficients relative to the base case. An exception is our results for synergies, which become noticeably stronger with year and industry dummies. Next, we use an alternative lottery index in which we replace the 
theoretically called for expected idiosyncratic skewness with lagged idiosyncratic skewness as in Kumar (2009). Our results on the offer price premium, synergies, and bidder returns are weaker, but still highly significant. If managers were actually using expected skewness in making their decisions, then this pattern is exactly what we would expect when we use lagged skewness as a noisy proxy for expected skewness in our regression. The coefficient on LIDX loses significance when target return (for which we have no clear theoretical prediction) is the dependent variable. Our results are therefore robust to using an alternative definition of the lottery index as in Kumar (2009).

Next, we include leverage and operating cash flow in our baseline regression as additional control variables. Since we include leverage, we exclude banks and financial firms (1-digit SIC code of 6 ) in this test. We find that the results are robust to including these additional controls. Next, we use the Amihud (2002) liquidity measure to control for potential differences in liquidity between lottery and non-lottery targets. Our results are not changed by the inclusion of this variable. We include the CAPM beta and coskewness, as measured in Harvey and Siddique (2000), to show that our results are indeed capturing idiosyncratic volatility and idiosyncratic skewness, which should not matter in more traditional economic models, rather than their systematic counterparts. Our results are robust to controlling for these variables. Lastly, we include the Z-Score of the bidder as additional control. There might be rational incentives for manager to gamble in distressed firms, or in firms closer to bankruptcy. Our results show that this is not what we are capturing in our lottery index. Similar to our sample splits, we do not find a change in our results when we control for the target Z-Score.

Under the overconfidence-hypothesis, managers pay a premium for lottery-type targets not because of their gambling attitudes, but because they are overconfident. We directly control for a measure of overconfidence based on stock option exercises by the bidder CEO (Malmendier and Tate (2008)) and find that, altough the additional data requirements cut our sample size in half, our results are effectively unchanged 19 Together with evidence in the following sections, we conclude that overconfidence is not what is driving the effects we

\footnotetext{
${ }^{19}$ As Malmendier and Tate (2008) use data from other sources than ExecuComp, and as they are analyzing a different time period, we follow Hirshleifer, Low, and Teoh (2010) in constructing the overconfidence measure based on ExecuComp data.
} 
document here.

The structure of executive compensation contracts in bidding firms could induce managerial risk seeking and thus be driving some of our results. ${ }^{20}$ To show empirically that the structure of executive pay is not driving our results we use two control variables. First, we follow Chava and Purnanandam (2009) and calculate the change in the value of the option holdings of the bidding firm's $\mathrm{CEO}$ for a change in firm volatility (CEO option vega). ${ }^{21}$ Second, we use ExecuComp to compute the three year average of option compensation to total compensation for the bidder CEO as a simple measure of contract convexity (CEO \% options). Table VI, Panel C shows that executive pay and the resulting risk taking incentives are not what we are capturing in our regressions.

Baker, Pan, and Wurgler (2009) show that the target's 52-week high serves as an important anchor for M\&A deal pricing. Even though our gambling argument is not linked to their 52-week high in any obvious way, we include the target's difference to its 52-week high as an additional control variable. These results show that our lottery measure is largely orthogonal to the reference point effect of Baker, Pan, and Wurgler (2009).

Chatterjee, John, and Yan (2009) suggest that divergence in opinion about the target's true value drives offer price premia. Following their work, as a robustness check, we rerun our benchmark regressions with analyst forecast dispersion and change in the breadth of mutual fund ownership as additional control variables to proxy for divergence of opinion. Our results show that divergence of opinion about the target's true value (the hard-to-value-hypothesis) does not explain our findings.

In a further test, we show that our results are not driven by the fact that we include both completed and non-completed deals. All inferences go through when we only use the subsample of completed deals. One conjecture about our results could be that they are driven largely by new economy stocks. While we already control for those stocks using a new economy dummy in our baseline regressions, we show here that the results are also very strong in the subsample of firms that do not belong to the new economy. We find that our results continue to hold, and get even slightly stronger, when we exclude transactions

\footnotetext{
${ }^{20}$ While arguably intuitive, it should be noted that the connection between convexity of compensation contracts and managerial risk appetite is theoretically ambiguous (Carpenter (2000), Ross (2004)).

${ }^{21}$ We refer the reader to their paper for details on the construction of the variable.
} 
with a deal size smaller than $1 \%$ of the bidder market capitalization. Stocks with low prices are attractive gambling objects. However, we observe that our results are fairly robust to excluding all stocks with a stock price below $\$ 5$, which shows that the general phenomenon is not restricted to very low priced stocks.

We winsorize all variables in our baseline regressions. To rule out that this affects our results, we reestimate median regressions as a alternative way to deal with outliers. We also report results without any winsorization. None of our results are materially affected. Finally, as an alternative to using percentage announcement returns, we compute dollar announcement returns and dollar synergies in a further test. The economic significance of our results is slightly larger in these tests than in our base estimates. In particular, a one standard deviation change in LIDX leads to a dollar value change in synergies of $\$ 23.7$ million $(=0.25 \times \$ \mathrm{~m} 94.6)$. The more noisy dollar values lead to a drop in the t-statistic on synergies to 1.10, but results continue to be highly significant for both bidder and target announcement returns.

Overall we conclude that our main results are robust to a battery of robustness checks.

\section{Additional Empirical Evidence}

In the previous section we have established that offer price premia and target announcement returns are higher, and both synergies and bidder announcement returns are lower in lottery acquisitions. In this section we test finer predictions of our hypothesis that managerial preferences are influencing M\&A pricing and provide additional evidence that gambling attitudes are driving our results.

\subsection{Impact of target on lotteryness of the combined firm}

If managers are concerned about the lotteryness of the overall firm, then the premia we document in Section 4 should be more pronounced when acquiring a lottery type target is more likely to increase the lotteryness of the combined firm (Hypothesis 5) ${ }^{22}$ To test this,

\footnotetext{
${ }^{22}$ Note that it is unlikely that all CEOs would focus on the combined firm. As documented for example in Kahneman and Lovallo (1993), a common problem in corporate decision making is that decisions are framed narrowly, i.e. that there is a tendency to view projects in isolation. If at least some CEOs frame the takeover decision narrowly, then we might observe significant premia even if targets are small and if their returns are not highly correlated with the bidder's. Our tests in this section therefore indicate that a substantial fraction
} 
we first replace the target lottery index LIDX, which we used in our previous regressions with a relative lottery index, RLIDX, which we define as the ratio of target lottery index and acquiror lottery index. Intuitively, we would only expect to see a lottery premium if the target looks more like a lottery than the acquiror, i.e. when RLIDX is high. Table VII, Panel A, presents results when we regress the offer price premium, synergies, and announcement returns on RLIDX and the full set of control variables used in Tables III to V. As expected, the offer price premium and target returns are higher, and synergies and acquiror returns are lower whenever the target has more upside potential than the acquiror.

As a second test, we conjecture that a gambling premium is more likely if the target is large enough relative to the acquiror to meaningfully influence the distribution of returns of the combined firm and if the target skewness is not be eliminated by diversification when the two firms are combined. We analyze subsamples to establish the claim empirically.

Specifically, we estimate the following model:

$$
\begin{aligned}
\text { DepVar }_{t} & =\text { SubVar }\left(\beta_{1} L I D X_{t-1}+\lambda_{1} \text { CONTROLS } S_{t-1}\right) \\
& +(1-\text { SubVar })\left(\beta_{2} L I D X_{t-1}+\lambda_{2} \text { CONTROL } S_{t-1}\right)+\epsilon_{t} .
\end{aligned}
$$

Here, DepVar is either synergies or announcement returns, and SubVar is an indicator function which is one if the observation belongs to the respective subsample and zero otherwise. We focus on synergies and acquiror announcement returns because this is where we have clear predictions across subsamples ${ }^{23}$ CONTROLS are control variables used in column 5 in Tables IV and V. For conciseness, we show only the coefficient on the lottery index LIDX, i.e. $\beta_{1}$ and $\beta_{2}$, and suppress the coefficients of the control variables. We also report the difference of $\beta_{1}$ and $\beta_{2}$ and the t-statistic for rejecting the null of $\beta_{1}=\beta_{2}$.

Table VII, Panel B, presents results from this subsample analysis. Columns 2 and 3 show that lottery targets that are large and in the same industry as the acquiror (and therefore of CEOs is not framing their decision narrowly when acquiring lottery type targets.

${ }^{23}$ As explained in Section 2, while finding higher offer price premium and target acquiror returns would provide evidence for our theory, not finding a positive relationship does not refute it. For example, if synergies are lower in lottery acquisitions, but the implicit gambling premium is higher, the net effect on target returns is ambiguous. Synergies and acquiror announcement returns do not suffer from this problem, which is why we focus on these variables. Unreported results (available upon request) show that in almost all subsamples presented in Section 5, effects for offer price premia and target returns are larger when gambling is more likely. There is not a single case where effects are significantly weaker in these subsamples. 
likely to be non-diversifying) are associated with stronger negative effects on both synergies and acquiror announcement returns. Columns 5 and 6 show the same pattern when the target is large relative to the acquiror and the ex ante correlation between target and bidder stock returns is high. Overall, these tests provide additional support for our gambling hypothesis by showing that gambling premia are large when the target's upside potential is likely to increase the upside of the combined firm (Hypothesis 5).

\subsection{The impact of managerial gambling propensity}

In this section we show that our effects are stronger when managerial gambling propensity is likely to be high (Hypothesis 6). Because of obvious data constraints, direct measures of gambling propensity on the manager level are unavailable. In a recent paper, Kumar, Page, and Spalt (2009) use a geographical identification strategy to measure gambling propensity on the county level and argue that local gambling norms have a strong influence on the personal gambling attitudes of individuals, and therefore also institutions and corporations, located in the county. They identify gambling propensity by the proportion of the local Catholic population relative to the local Protestant population, drawing on a large body of evidence showing that Catholics, on average, gamble significantly more. They show that the ratio of Catholics to Protestants (CPRATIO) captures the gambling attitudes of both retail investors as well as institutional investors and corporations headquartered in the county. In our first test, we compute CPRATIO annually for all US counties and assign them to the high category if CPRATIO is in the top terzile across counties in that year, and to the low category otherwise. If our effects are reflecting gambling attitudes, then we should see stronger effects in the high CPRATIO subsample, which is where local gambling propensity is strongest (Hypothesis 6). Because CPRATIO is related to demographic factors that could themselves be influencing our results, we follow Kumar, Page, and Spalt (2009) and include in these regressions total county population, average educational attainment in the county, percentage of minority households, the male-female-ratio, age, and the fraction of inhabitants in urban areas 24

Columns 2 and 3 in Table VIII, Panel A, present results. Consistent with our gambling hypothesis, LIDX influences synergies and acquiror announcement returns significantly only

\footnotetext{
${ }^{24}$ We obtain these data from the U.S. Census Bureau.
} 
if CPRATIO is high. Both synergies and acquiror announcement returns are significantly lower for lottery acquisitions when managers are more likely to gamble. The significant difference between the subsamples suggests that the value destroying effect of lottery acquisitions is concentrated in the subsample where we would ex ante expect managerial gambling propensity to be higher. Overall, we conclude that the evidence from analyzing CPRATIO subsamples strongly supports Hypothesis 6.

The predictions on CPRATIO are a unique implication of our gambling conjecture. The above findings are therefore useful in distinguishing gambling from overconfidence. Since it is not obvious why Catholics should be more overconfident than Protestants, our effects cannot plausibly be driven by overconfidence. Hence, the bias we uncover is new to the behavioral merger literature. The findings also show that our results are not simply driven by the fact that lottery firms are exactly those firms for which valuation exercises are hardest, which might make it easier for managers to argue for higher prices. Since the valuation of lottery firms should not be more difficult for acquirors from Catholic regions than for acquirors from Protestant regions, the difference in our effects across these regions cannot be explained by valuation difficulties. Lastly, since agency and career concerns are not related to the local religion in obvious ways, our results do not seem to be driven mainly by this alternative explanation.

We also consider heightened propensity to gamble induced by macroeconomic conditions. If business opportunities deteriorate in economic downturns, then gambling is likely to become more attractive, consistent with existing evidence from lottery-ticket sales and retail investment in lottery stocks (Brenner and Brenner (1990), Mikesell (1994), Kumar (2009)). As a measure of economic conditions, we use the Chicago Fed National Activity Index (CFNAI), which is a monthly index designed to gauge overall economic activity by combining information in 85 separate economic indicators on production and income, employment, unemployment and hours, personal consumption and housing, sales, orders, and inventories. The index is constructed such that a positive (negative) index value indicates economic growth above (below) the trend.

Columns 5 and 6 in Table VIII, Panel A, show results when we split our sample by positive and negative CFNAI index values two months prior to the announcement. The 
pattern we document is similar to the CPRATIO split. The magnitudes of the coefficients on LIDX in synergy and announcement return regressions are much larger for the negative CFNAI values subsample, consistent with the hypothesis that bad economic conditions make gambling relatively more attractive. The difference of the lottery effect has the predicted sign in both settings and is statistically significant. Overall, these results suggest that lottery acquisitions become more attractive in economic downturns.

As a final test on gambling propensity, we conjecture that younger CEOs are more prone to gambling. This conjecture is based on prior literature which shows that preference for lottery tickets and skewness in investment returns tends to be negatively correlated with age (e.g., Goetzmann and Kumar (2008), Kumar (2009)). Columns 8 and 9 show results when we split our sample by age of the bidding firm's CEO. In order to distinguish a possible entrenchment effect from the age effect we are interested in, we include CEO tenure as an additional control variable in these regressions. Since data for CEO age and tenure is only available from ExecuComp for a relatively small subset of bidder firms we lose about three quarters of our observations in this test. Still, the results are clear: younger CEOs are associated with more pronounced gambling effects. In particular, as shown by the highly significant differences between the subsamples, younger CEOs destroy significantly more wealth for their shareholders, and the lottery acquisitions they engage in come with significantly lower synergies.

Overall, the patterns we document provide strong support for Hypothesis 6 and suggest that managerial gambling attitudes influence takeover decisions.

\subsection{The impact of managerial discretion}

Hypothesis 7 states that managerial gambling attitudes should be more likely to influence M\&A pricing if the top decision makers are more entrenched or otherwise shielded from competitive forces which would contain overpayment. We test this hypothesis by using three well-known measures of managerial discretion. The first measure is the corporate governance index (GIM) of Gompers, Ishii, and Metrick (2003), the second measure is the ownership stake of the CEO, and the third measure is the level of product market competition (Giroud 
and Mueller (2010)) 25

Columns 2 and 3 of Table VIII, Panel B, present results when we split the sample by the GIM index of the acquiror (since the index is available only for a subset of firms and years, we lose many observations in this test). We observe that firms with a high GIM index (which Gompers, Ishii, and Metrick (2003) label "dictatorship" firms) are much more sensitive to the lottery characteristics of the target. By contrast, the effects for firms with low GIM index values ("democracies") are much weaker, supporting the view that the threat of replacing underperforming managements enforces some discipline to the pricing of M\&A deals and contains the tendency of managers to gamble on acquisitions.

As a second test of our management discretion hypothesis we split our sample by CEO ownership (columns 5 and 6). Following Morck, Shleifer, and Vishny (1988), we conjecture that CEOs with very large ownership stakes are more entrenched ${ }^{26}$ Again we lose a considerable amount of observations due to data availability. Still, consistent with Hypothesis 7 we find that acquirors with high CEO ownership have significantly smaller coefficients on LIDX in the synergy and acquiror announcement return regressions.

We find very similar results when we split the sample by the fierceness of product market competition in the acquiror's 3-digit SIC code industry (columns 8 and 9 of Table VIII, Panel B). Stronger competition in product markets makes it more costly to lose value on bad acquisitions and induces an incentive to invest into good project appraisal processes. Consistent with this idea, we find that bidders in weaker competitive environments have lower synergies and lower acquiror announcement returns in lottery acquisitions, while these effects are muted for bidders in highly competitive product markets. In both cases, the differences are also statistically significant. Overall, these results strongly support Hypothesis 7.

Top sum up, the results in this section document that value destruction in lottery acquisitions is stronger when managers have more discretion and are more entrenched.

\footnotetext{
${ }^{25}$ We obtain very similar results when we use the E-Index proposed by Bebchuk, Cohen, and Ferrell (2009), which uses a subset of the variables in the GIM-Index.

${ }^{26}$ We use CEO ownership rather than ownership of the top management team because we focus on CEO entrenchment. All results remain qualitatively unchanged, however, if we use total ownership of the top management team. The average ownership stake in the high CEO ownership sample is $4.9 \%$. This value is close to the $5 \%$ threshold for which Morck, Shleifer, and Vishny (1988) find negative effects from entrenchment on firm valuation. As Morck, Shleifer, and Vishny (1988) consider the whole management team, rather than the CEO, the $4.9 \%$ average ownership we have in the high ownership sample can plausibly be interpreted as large.
} 


\subsection{Gambling for resurrection}

In this section we test if our results are stronger when prior firm underperformance would induce managers to find gambling to break even more attractive (Hypothesis 8) 27 We operationalize this idea by suggesting three specific situations in which managers feel the desire to enter a gamble to break even. First, we conjecture that a manager will feel like an underperformer if the firm's stock return has been particularly low over the last year. Second, the more the stock price of the acquiror is below its 52 -week high, the more likely it is that the manager feels to be in the loss space. Lastly, we use an accounting measure and conjecture that gambling on an acquisition success is more likely if the firm has reported negative net income in the previous fiscal year.

Table VIII, Panel C, presents results. In all three settings we find evidence consistent with our gambling hypothesis. The impact of LIDX on synergies and announcement returns is much stronger if the manager is more likely to feel being in the loss space, which would increase his propensity to gamble. Specifically, both synergies and acquiror announcement returns are much smaller for lottery acquisitions if the firm has performed poorly over the last 12 months, if the difference of the current stock price to the 52-week high is large, or if the firm has reported negative earnings at the last fiscal year end. This evidence provides clear support of Hypothesis 8. Since it seems implausible to assume that managers in underperforming firms are more optimistic and overconfident than managers in recently successful firms, our results in this section reinforce our earlier conclusion that overconfidence and optimism cannot explain our findings ${ }^{28}$

\subsection{Summary of subsample tests and economic significance}

The consistency of our results across many different subsample tests is striking. Figure 1 illustrates this by showing the implied change in synergies and acquiror announcement return

\footnotetext{
${ }^{27}$ This behavior of "gambling for resurrection" is consistent with many experiments as, for example, in Kahneman and Tversky (1979), Thaler and Johnson (1990).

${ }^{28}$ The view that underperforming managers are exactly those for which we should expect lower overconfidence levels is consistent with self-serving attribution bias which captures the tendency of decision makers to credit themselves for successes and blame others for failure. Gervais and Odean (2001) develop a theoretical model to explain why overconfidence and prior successes are positively correlated.
} 
for a one standard deviation change in the lottery index LIDX, based on the coefficients in Table VIII. Consistent with our gambling hypothesis, synergies and returns to acquiring firm shareholders are substantially lower in all subsamples where we expect gambling propensity of managers to be higher. In addition to showing that our effects obtain in many different settings, Figure 1 documents that the magnitudes of our effects are economically significant. A one standard deviation change in LIDX decreases synergies by an additional 43bp to 154bp, and acquiror announcement returns by an additional 42bp to 178bp, in the subsample where gambling attitudes are likely to be important. The sample average is $1.55 \%$ for synergies and $-1.69 \%$ for bidder returns, hence these effects are large.

\subsection{Acquisition "style" and takeover probability}

We have shown that greater gambling propensity and greater managerial discretion leads to deals that are less successful. In this section we investigate if the lottery features of the target influences the acquisition "style" of the acquiror, by which we mean the lottery characteristics of the average deal, and if the target lottery features influence the probability of being acquired (Hypothesis 9).

Table IX presents results when we regress the average value of LIDX per acquiror on our measures of gambling propensity and discretion used in the previous sections. We control for the full set of variables in Table III, specification (5), i.e. we collapse the data set on the acquiror-year level, and cluster standard errors on the firm level in these regressions. With the sole exception of the GIM index, all 9 measures of gambling propensity and discretion are positively associated with average LIDX. Hence, the more likely a manager is to gamble, or the more power he has to influence the takeover decision, the more will the average acquisition of the firm be tilted towards being "lottery-like". This suggests that managerial gambling attitudes can impact corporate acquisition "style".

Next, we investigate if lottery-type firms have a higher likelihood of being taken over. We follow Palepu (1986) and Ambrose and Megginson (1992) in constructing the data set and in the control variables we use. The basis for this analysis is the Compustat file from 1987 to 2008 and we classify a firm as takeover target in the last year for which we have data on the firm if Compustat reports "Acquisition or Merger" as reason for deletion from the active file. Similar to Palepu (1986) and Ambrose and Megginson (1992) we match the 
takeover targets to several subsets of firms that have not been taken over during the sample period. For all firms each fiscal year $t$, LIDX is taken to be the end-of-December value of calendar year $t \stackrel{29}{2}$

Table X presents results from Probit regressions, where the dependent variable is one if the firm is taken over in the fiscal year. Standard errors are robust to heteroscedasticity and robust to clustering at the firm level. We first use the full sample of non-target firms as a benchmark for our target firms and find that the lottery index is strongly positively related to the takeover probability $(t$-statistic $=8.88)$, both with and without controls for year and two digit SIC code industry (specifications (1) and (2)). Next, we refine the set of control firms by selecting for each year only the subset of firms in the same four digit SIC code if there was at least one takeover in this industry. The characteristics of these non-target firms should thus more closely resemble the characteristics of potential targets that could have been taken over but were not. Again, we find that lottery type firms are more likely to be acquisition targets. Lastly, we match by industry and size and require that the set of control firms is restricted to only the subset of firms in those four digit SIC code/size decile combinations in which there was at least one takeover in the year. Also here, LIDX is strongly positively related to the takeover probability even controlling for a large set of control variables suggested by the prior literature as well as year and industry fixed effects. A one standard deviation change in LIDX leads to a 1.2 percentage point change in the takeover probability, which, relative to the sample mean takeover probability of $8.2 \%$ represents an increase of about $14.6 \%$ (this is based on specification (6)). Overall, these results complement the findings in Graham, Harvey, and Puri (2009), who find that managers with higher gambling propensity make more acquisitions. The results strongly support our hypothesis that the gambling attractiveness of a target influences takeover decisions.

\subsection{Lottery acquisitions and synergies}

As a final piece of evidence, we analyze the relation between actual synergy forecasts and lottery acquisitions. The underlying motivation is that managers might actually gamble on large gains from synergies in the deal (Hypothesis 10). To analyze this possibility, we use

\footnotetext{
${ }^{29}$ All results are unchanged when we use end-of-July values, instead.
} 
a hand-collected dataset consisting of synergy forecasts announced by the acquiring firm 30 The dataset spans the period from 1990 to 2005. Table XI presents results when we match it with the dataset used in previous sections. First, we find that the publication of synergy forecasts is less common in lottery acquisitions (columns 1 and 4). Given potential legal relevance of inflated synergy forecasts, this perhaps reflects that at least some CEOs realize that they are bidding on the high side. Note that we are controlling for the full set of firm and deal characteristics used previously, so differences along these dimensions between lottery and non-lottery deals cannot explain the result.

Next, we find that conditional on providing a synergy forecast, these forecasts are higher if the target is of lottery type. This is consistent with an upward bias in the assessment of potential gains from synergies. To address potential sample selection issues (since the decision to make a synergy forecast might be endogenous) we run Heckman two stage regressions with the probit models in columns 1 and 4 as first stages, respectively.

Lastly, we document in columns 3 and 6, that the positive effect of an additional projected dollar of synergies is lower for lottery acquisitions. This pattern is particularly striking, as it provides strong evidence for the view that the market takes into account the propensity of managers to pay a premium for upside potential and therefore discounts the positive information conveyed by higher synergy forecasts (Hypothesis 10). Overall these patterns suggest that synergies are one channel through which a preference for upside potential becomes operational.

\section{Conclusion}

In this paper we conjecture that gambling attitudes among top managers are important for takeover decisions. Our work is motivated by well-known stylized facts of individual decision making. In particular the preference for lottery-like skewed payoffs might have tangible effects on deal pricing and market reactions to merger bids. To test this conjecture we first form an index measuring how much a target firm's stock shares salient characteristics of attractive gambles: high skewness and volatility, and low price. We then show that offer price

\footnotetext{
${ }^{30}$ The data set was used in Bernile and Bauguess (2010) and Bernile and Lyandres (2011) and we refer the reader to these papers for details on the dataset construction. We thank Gennaro Bernile for providing us with the data.
} 
premia and target announcement returns are higher, and synergies and bidder announcement returns are lower in transactions involving targets with these gambling features.

Biases among top decision makers will be more likely to enter M\&A pricing if the bias is stronger, or if managers have more discretion in making decisions. Testing these finer predictions, we find that our effects are concentrated among firms headquartered in counties in which the local populations is likely to find gambling attractive, for firms in which managers are more entrenched, for younger acquiring-firm CEOs, for firms facing weaker product market competition, during economic downturns, and in situations where the firm has recently performed poorly, giving managers an incentive to gamble to break even. Overall, we interpret our results as strong evidence suggesting that managerial gambling attitudes matter for M\&A pricing. Our main result is that the value destruction for acquiring-firm shareholders from our gambling effect is substantial. It is similar in magnitude (if not larger) than other documented first-order effects, including the reference point effect of Baker, Pan, and Wurgler (2009), the overconfidence effect of Malmendier and Tate (2008), and the small acquiror effect documented by Moeller, Schlingemann, and Stulz (2004).

Our findings have several important implications. In the context of corporate governance we suggest a new channel, gambling in acquisitions, through which managers might jeopardize shareholder wealth. Specifically, our analysis indicates that lower synergies in lottery acquisitions are an important way in which managerial gambling preferences manifest themselves in takeovers. While accurately estimating expected synergies is crucial, it is also an extremely difficult task for boards and shareholders. Our study shows that benefits for boards and shareholders from constraining managerial gambling can be economically large.

While our paper analyzes "gambling attitudes" in general, future research should make progress in identifying which of the potential underlying preference structures is likely to give rise to the observed gambling effects. Perhaps a natural interpretation would be in terms of the probability weighting function in prospect theory. If probability weighting were the ultimate driver of our effects, then our results and the work by Baker, Pan, and Wurgler (2009), which shows that reference points are important, would jointly suggest that prospect theory is particularly relevant in understanding how top managers make decisions. 


\section{References}

Altman, Edward I., 1968, Financial ratios, discriminant analysis and the prediction of corporate bankruptcy, Journal of Finance 23, 589-609.

Ambrose, Brent W., and William L. Megginson, 1992, The role of asset structure, ownership structure, and takeover defenses in determining acquisition likelihood, Journal of Financial and Quantitative Analysis 27, 575-589.

Amihud, Yakov, 2002, Illiquidity and stock returns: Cross-section and time-series effects, Journal of Financial Markets 5, 31-56.

— , and Baruch Lev, 1981, Risk reduction as a managerial motive for conglomerate mergers, The Bell Journal of Economics 12, pp. 605-617.

Andrade, Gregor, Mark Mitchell, and Erik Stafford, 2001, New evidence and perspectives on mergers, Journal of Economic Perspectives 15, 103-120.

Ang, Andrew, Robert J. Hodrick, Yuhang Xing, and Xiaoyan Zhang, 2006, The cross-section of volatility and expected returns, Journal of Finance 61, 259-299.

— 2009, High idiosyncratic volatility and low returns: International and further U.S. evidence, Journal of Financial Economics 91, 1-23.

Baker, Malcolm, Xin Pan, and Jeffrey Wurgler, 2009, A reference point theory of mergers and acquisitions, Working Paper, New York University; Available at SSRN: http://ssrn.com/paper=1364152.

Baker, Malcolm, Richard Ruback, and Jeffrey Wurgler, 2008, Behavioral corporate finance: A survey, In: The Handbook of Corporate Finance: Empirical Corporate Finance (edited by Espen Eckbo) New York: Elsevier/North Holland.

Baker, Malcolm, and Jeffrey Wurgler, 2006, Investor sentiment and the cross-section of stock returns, Journal of Finance 61, 1645-1680.

, 2007, Investor sentiment in the stock market, Journal of Economic Perspectives 21, $129-151$.

Bali, Turan G., Nusret Cakici, and Robert Whitelaw, 2009, Maxing out: Stocks as lotteries and the cross-section of expected returns, Working Paper (March), New York University; Available at SSRN: http://ssrn.com/abstract=1262416.

Barberis, Nicholas, and Ming Huang, 2008, Stocks as lotteries: The implications of probability weighting for security prices, American Economic Review 98, 2066-2100.

Bebchuk, Lucian, Alma Cohen, and Allen Ferrell, 2009, What matters in corporate governance?, Review of Financial Studies 22, 783-827.

Ben-David, Itzhak, John R. Graham, and Campbell R. Harvey, 2010, Managerial Miscalibration, Working Paper, Duke University. 
Bernile, Gennaro, and Scott Bauguess, 2010, Do merger synergies exist?, Working Paper; Available at SSRN: http://ssrn.com/abstract $=642322$.

Bernile, Gennaro, and Evgeny Lyandres, 2011, Do merger-related operating efficiencies have strategic effects along the supply chain?, Working Paper, University of Miami.

Bertrand, Marianne, and Antoinette Schoar, 2003, Managing with style: The effect of managers on firm policies, The Quarterly Journal of Economics 118, pp. 1169-1208.

Betton, Sandra, B. Espen Eckbo, and Karin S. Thorburn, 2008, Corporate takeovers, In: The Handbook of Corporate Finance: Empirical Corporate Finance (edited by Espen Eckbo) New York: Elsevier/North Holland.

Boyer, Brian, Todd Mitton, and Keith Vorkink, 2010, Expected idiosyncratic skewness, Review of Financial Studies 23, 169-202.

Bradley, Michael, Anand Desai, and E. Han Kim, 1988, Synergistic gains from corporate acquisitions and their division between the stockholders of target and acquiring firms, Journal of Financial Economics 21, 3-40.

Brav, Alon, Michael Brandt, John Graham, and Alok Kumar, 2010, The idiosyncratic volatility puzzle: Time trend or speculative episodes?, Review of Financial Studies 23, 863-899.

Brav, Alon, and Paul A. Gompers, 1997, Myth or reality? the long-run underperformance of initial public offerings: Evidence from venture and nonventure capital-backed companies, The Journal of Finance 52, pp. 1791-1821.

Brenner, Reuven, and Gabrielle A. Brenner, 1990, Gambling and Speculation (Cambridge University Press, Cambridge, UK).

Brunnermeier, Markus K., Christian Gollier, and Jonathan A. Parker, 2007, Optimal beliefs, asset prices, and the preference for skewed returns, American Economic Review 97, 159165.

Brunnermeier, Markus K., and Jonathan A. Parker, 2005, Optimal expectations, American Economic Review 95, 1092-1118.

Campbell, John Y., Jens Hilscher, and Jan Szilagyi, 2008, In search of distress risk, Journal of Finance 63, 2899-2939.

Carpenter, Jennifer N., 2000, Does option compensation increase managerial risk appetite?, Journal of Finance 55, 2311-2331.

Chatterjee, Sris, Kose John, and An Yan, 2009, Takeovers and divergence of investor opinion, SSRN eLibrary.

Chava, Sudheer, and Amiyatosh K. Purnanandam, 2009, CEOs vs. CFOs: Incentives and corporate policies, Journal of Financial Economics forthcoming.

Coles, Jeffrey L., Naveen D. Daniel, and Lalitha Naveen, 2006, Managerial incentives and risk-taking, Journal of Financial Economics 79, 431 - 468. 
Coval, Joshua D., and Tyler Shumway, 2005, Do behavioral biases affect prices?, Journal of Finance 60, 267-306.

Dorn, Daniel, and Paul Sengmueller, 2009, Trading as entertainment, Management Science $55,591-603$.

Fama, Eugene F., and Kenneth R. French, 1993, Common risk factors in returns on stocks and bonds, Journal of Financial Economics 33, 3-56.

Friedman, Milton, and Leonard J. Savage, 1948, The utility analysis of choices involving risk, Journal of Political Economy 56, 279-304.

Gervais, Simon, and Terrance Odean, 2001, Learning to be overconfident, Review of Financial Studies 14, 1-27.

Giroud, Xavier, and Holger M. Mueller, 2010, Does corporate covernance matter in competitive industries?, Journal of Financial Economics 95, 312-331.

Goetzmann, William N., and Alok Kumar, 2008, Equity portfolio diversification, Review of Finance 12, 433-463.

Golec, Joseph, and Maurry Tamarkin, 1998, Bettors love skewness, not risk, at the horse track, Journal of Political Economy 106, 205-225.

Gompers, Paul, Joy Ishii, and Andrew Metrick, 2003, Corporate governance and equity prices, The Quarterly Journal of Economics 118, 107-155.

Graham, John R., Campbell R. Harvey, and Manju Puri, 2009, Managerial Attitudes and Corporate Actions, Working Paper, Duke University.

— , 2010, Capital Allocation and Delegation of Decision-Making Authority Within Firms, Working Paper, Duke University.

Green, T. Clifton, and Byoung-Hyoun Hwang, 2009, IPOs as lotteries: Expected skewness and first-day returns, Working Paper (December), Emory University. Available at SSRN: http://ssrn.com/paper=1374993.

Haigh, Michael S., and John A. List, 2005, Do professional traders exhibit myopic loss aversion? An experimental analysis, The Journal of Finance 60, 523-534.

Harvey, Campbell R., and Akhtar Siddique, 2000, Conditional skewness in asset pricing tests, Journal of Finance 55, 1263-1295.

Hirshleifer, David A., Angie Low, and Siew Hong Teoh, 2010, Are overconfident ceos better innovators?, Working Paper; Available at SSRN: http://ssrn.com/abstract=1598021.

Hirshleifer, David A., and Anjan Thakor, 1992, Managerial conservatism, project choice, and debt, Review of Financial Studies 5, 437-470.

Jensen, Michael C., 1986, Agency costs of free cash flow, corporate finance, and takeovers, American Economic Review 76, 323-329. 
Kachelmeier, Steven J., and Mohamed Shehata, 1992, Examining risk preferences under high monetary incentives: Experimental evidence from the people's republic of china, The American Economic Review 82, pp. 1120-1141.

Kahneman, Daniel, and Dan Lovallo, 1993, Timid choices and bold forecasts: A cognitive perspective on risk taking, Management Science 39, 17-31.

Kahneman, Daniel, and Amos Tversky, 1979, Prospect theory: An analysis of decision under risk, Econometrica 47, 263-291.

Kraus, Alan, and Robert H. Litzenberger, 1976, Skewness preference and the valuation of risky assets, Journal of Finance 31, 1085-1100.

Kumar, Alok, 2009, Who gambles in the stock market?, Journal of Finance 64, 1889-1933.

— - Jeremy Page, and Oliver Spalt, 2009, Religious beliefs, gambling attitudes, and financial market outcomes, Journal of Financial Economics forthcoming.

Lang, Larry, René Stulz, and Ralph Walkling, 1991, A test of the free cash flow hypothesis: The case of bidder returns, Journal of Financial Economics 29, 315 - 335.

List, John A., 2003, Does market experience eliminate market anomalies?, Quarterly Journal of Economics 118, 41-71.

Loughran, Tim, and Jay R. Ritter, 1995, The new issues puzzle, The Journal of Finance 50, pp. $23-51$.

MacKie-Mason, Jeffrey K., 1990, Do taxes affect corporate financing decisions?, Journal of Finance 45, 1471-1493.

Malmendier, Ulrike, and Geoffrey Tate, 2005, Ceo overconfidence and corporate investment, The Journal of Finance 60, pp. 2661-2700.

— 2008, Who makes acquisitions? CEO overconfidence and the market's reaction, Journal of Financial Economics 89, 20-43.

Masulis, Ronald, Cong Wang, and Fei Xie, 2007, Corporate governance and acquirer returns, Journal of Finance 62, 1851-1889.

Mikesell, John L., 1994, State lottery sales and economic activity, National Tax Journal 47, 165-171.

Mitton, Todd, and Keith Vorkink, 2007, Equilibrium under-diversification and the preference for skewness, Review of Financial Studies 20, 1255-1288.

Moeller, Sara B., Frederik P. Schlingemann, and René M. Stulz, 2004, Firm size and the gains from acquisitions, Journal of Financial Economics 73, 201-228.

Morck, Randall, Andrei Shleifer, and Robert W. Vishny, 1988, Management ownership and market valuation an empirical analysis, Journal of Financial Economics 20, 293-315. 
— 1990, Do managerial objectives drive bad acquisitions?, Journal of Finance 45, $31-48$.

Oyer, Paul, and Scott Schaefer, 2004, Why do some firms give stock options to all employees? An empirical examination of alternative theories, Journal of Financial Economics 76, 99133.

Palepu, Krishna G., 1986, Predicting takeover targets - a methodological and empirical analysis, Journal of Accounting and Economics 8, 3-35.

Polkovnichenko, Valery, 2005, Household portfolio diversification: A case for rank-dependent preferences, Review of Financial Studies 18, 1467-1502.

Roll, Richard, 1986, The hubris hypothesis of corporate takeovers, The Journal of Business 59, 197-216.

Ross, Stephen A., 2004, Compensation, incentives, and the duality of risk aversion and riskiness, Journal of Finance 59, 207-225.

Shiller, Robert J., 2000, Irrational Exuberance (Princeton University Press, Princeton, NJ).

Thaler, Richard H., and Eric J. Johnson, 1990, Gambling with the house money and trying to break even: The effects of prior outcomes on risky choice, Management Science 36, $643-660$.

Treynor, Jack, and Fisher Black, 1976, Corporate investment decisions, Modern Developments in Financial Management S. Myers (Editor), New York Praeger Publisher.

Tversky, Amos, and Daniel Kahneman, 1992, Advances in prospect theory: Cumulative representation of uncertainty, Journal of Risk and Uncertainty 5, 297-323.

Weld, William C., Shlomo Benartzi, Roni Michaely, and Richard H. Thaler, 2009, The nominal prize puzzle, Journal of Economic Perspectives 23, 121-142. 


\section{TABLE I}

\section{Sample}

This table shows the number of acquisitions by year and the lottery characteristics of targets in those acquisitions as measured by the lottery index LIDX. LIDX measures the similarity of the stock of the target with salient features of attractive gambles (low price, high idiosyncratic volatility and expected idiosyncratic skewness). LIDX increases in the attractiveness of the target as a gamble. We form high and low groups by splitting the pooled sample at the median value of LIDX. See Appendix Table A.I for a definition of LIDX.

\begin{tabular}{ccccc}
\hline \hline Year & Full Sample & High LIDX & Low LIDX & \% High LIDX \\
\hline 1987 & 186 & 91 & 95 & $48.9 \%$ \\
1988 & 297 & 141 & 156 & $47.5 \%$ \\
1989 & 224 & 120 & 104 & $53.6 \%$ \\
1990 & 123 & 63 & 60 & $51.2 \%$ \\
1991 & 96 & 47 & 49 & $49.0 \%$ \\
1992 & 113 & 58 & 55 & $51.3 \%$ \\
1993 & 184 & 96 & 88 & $52.2 \%$ \\
1994 & 259 & 130 & 129 & $50.2 \%$ \\
1995 & 322 & 156 & 166 & $48.4 \%$ \\
1996 & 332 & 156 & 176 & $47.0 \%$ \\
1997 & 425 & 165 & 260 & $38.8 \%$ \\
1998 & 477 & 224 & 253 & $47.0 \%$ \\
1999 & 550 & 240 & 310 & $43.6 \%$ \\
2000 & 445 & 188 & 257 & $42.2 \%$ \\
2001 & 317 & 169 & 148 & $53.3 \%$ \\
2002 & 183 & 107 & 76 & $58.5 \%$ \\
2003 & 241 & 152 & 89 & $63.1 \%$ \\
2004 & 204 & 93 & 111 & $45.6 \%$ \\
2005 & 222 & 119 & 103 & $53.6 \%$ \\
2006 & 272 & 140 & 132 & $51.5 \%$ \\
2007 & 304 & 132 & 172 & $43.4 \%$ \\
2008 & 228 & 129 & 99 & $56.6 \%$ \\
\hline \hline Total & 6,004 & 2,916 & 3,088 & $48.6 \%$ \\
\hline \hline
\end{tabular}




\section{TABLE II}

\section{Summary Statistics}

This table displays descriptive statistics for the main variables used in our analysis. The lottery index LIDX measures the similarity of the stock of the target with salient features of attractive gambles. LIDX increases in the attractiveness of the target as a gamble. The constituents of LIDX are the price of the target's stock (Price), expected idiosyncratic skewness (EISKEW), and idiosyncratic volatility (IVOLA), all measured at the end of the second month prior to the month of the announcement. ROA is the bidder (target) firm return on assets from the last fiscal year before the takeover announcement. BM is the bidder (target) firm book to market ratio at the last fiscal year end before the takeover announcement. MCAP is the bidder (target) firm market capitalization at the last fiscal year end before the takeover announcement. Relative size is the transaction value over bidder's market capitalization at the last fiscal year end before the takeover announcement. New economy is a dummy variable indicating that the target is a new economy firm (SIC codes 3570 to $3579,3661,3674,5045,5961$, or 7370 to 7379 ). OPP is the offer price premium defined as the bid price over the target's stock price 4 weeks before the takeover announcement minus one. $\mathrm{A}(\mathrm{T}) \mathrm{CAR}[-1,+1]$ are bidder (target) announcement returns computed using the $[-1,+1]$ event window and a market model estimated over days [-280,-31]. Synergy $[-1,+1]$ is defined as weighted sum (by market capitalization) of the bidder and target cumulative abnormal announcement returns following Bradley, Desai, and Kim (1988). Cash (Stock) is a dummy variable indicating that a deal is financed with cash (stock) only. Tender is a dummy variable indicating a tender offer. Hostile is a dummy variable indicating hostile deals. Conglomerate is a dummy variable indicating that bidder and target are in a different 2-digit SIC code industry. Competed is a dummy variable indicating deals with more than one bidder. $\log$ (Number of Deals) is the natural $\log$ of the number of sample transactions in the target's 2-digit SIC code industry in the year of the takeover announcement. CPRATIO is the ratio of Catholic to Protestant population in the county where the headquarter of the bidder is located. The CFNAI is the Chicago Fed National Activity Index. CEO age is the age of bidding firm's CEO. The GIM-Index is an index developed by Gompers, Ishii, and Metrick (2003) measuring management entrenchment (of the bidding firm). Product market competition (PM Competition) is the Herfindahl index (sum of squared market shares measured in sales) in the acquiror's 3-digit SIC code industry. CEO ownership is the percentage ownership of the bidder firm's CEO. RET12 is the cumulative return of the bidder's stock calculated over months $t-13$ to $t-2$ for a takeover announcement in month $t$. DIFF52 is the ratio of the bidder's stock price at the end of month $t-2$ and the 52 -week high over months $t-13$ to $t-2$ minus one. Negative Net Income is a dummy variable equal to one if net income of the bidder was negative at last fiscal year end. See Appendix Table A.1 for a detailed overview of variable definitions. 
TABLE II (Continued)

Summary Statistics

\begin{tabular}{|c|c|c|c|c|c|c|c|c|}
\hline Variable & Mean & Median & SD & Min & $25^{t h}$ pctl. & $75^{t h}$ pctl. & Max & $\mathrm{N}$ \\
\hline \multicolumn{9}{|l|}{ Lottery variables } \\
\hline LIDX & 0.50 & 0.49 & 0.25 & 0.00 & 0.30 & 0.70 & 1.00 & 6,004 \\
\hline EISKEW & 0.74 & 0.68 & 0.55 & -0.40 & 0.36 & 1.04 & 2.42 & 6,004 \\
\hline IVOLA & 3.68 & 3.21 & 2.03 & 0.68 & 2.24 & 4.60 & 18.69 & 6,004 \\
\hline Price & 16.69 & 12.64 & 15.74 & 0.07 & 5.66 & 23.18 & 223.56 & 6,004 \\
\hline \multicolumn{9}{|c|}{ Acquiror and target characteristics } \\
\hline Acquiror ROA & 0.02 & 0.03 & 0.13 & -0.77 & 0.01 & 0.08 & 0.22 & 3,669 \\
\hline Acquiror BM Ratio & 0.66 & 0.46 & 0.97 & 0.04 & 0.27 & 0.72 & 8.08 & 3,615 \\
\hline Acquiror MCAP (\$bn) & 8.48 & 1.30 & 22.07 & 0.01 & 0.30 & 5.19 & 140.90 & 3,673 \\
\hline Target ROA & -0.03 & 0.01 & 0.20 & -1.09 & -0.02 & 0.06 & 0.24 & 5,729 \\
\hline Target BM Ratio & 0.78 & 0.64 & 0.60 & 0.05 & 0.40 & 0.97 & 3.72 & 5,564 \\
\hline Target MCAP (\$bn) & 0.64 & 0.11 & 1.76 & 0.00 & 0.04 & 0.40 & 12.98 & 5,839 \\
\hline Relative Size & 0.60 & 0.24 & 1.14 & 0.00 & 0.07 & 0.66 & 8.49 & 3,669 \\
\hline New Economy & 0.16 & 0 & 0.37 & 0 & 0 & 0 & 1 & 6,000 \\
\hline \multicolumn{9}{|l|}{ Deal characteristics } \\
\hline $\mathrm{OPP}$ & 42.97 & 35.25 & 44.71 & -52.20 & 18.05 & 58.61 & 300.00 & 5,860 \\
\hline $\operatorname{ACAR}[-1,+1](\%)$ & -1.69 & -1.21 & 6.98 & -23.44 & -4.81 & 1.63 & 20.36 & 3,683 \\
\hline$\$$ ACAR $[-1,+1](\$ \mathrm{~m})$ & -132.23 & -6.39 & 748.31 & $-4,798.55$ & -78.46 & 14.70 & $1,886.79$ & 3,531 \\
\hline TCAR $[-1,+1](\%)$ & 20.74 & 16.41 & 22.69 & -22.16 & 5.52 & 30.59 & 111.96 & 6,003 \\
\hline$\$ \operatorname{TCAR}[-1,+1](\$ \mathrm{~m})$ & 99.78 & 16.10 & 272.41 & -90.52 & 2.77 & 65.77 & $1,919.96$ & 5,837 \\
\hline Synergy $[-1,+1](\%)$ & 1.55 & 0.99 & 7.02 & -19.18 & -1.97 & 4.64 & 25.95 & 3,531 \\
\hline \$Synergy $[-1,+1](\$ \mathrm{~m})$ & -1.14 & 5.85 & 769.53 & $-4,155.27$ & -31.75 & 74.32 & $3,423.41$ & 3,531 \\
\hline Cash & 0.40 & 0 & 0.49 & 0 & 0 & 1 & 1 & 6,004 \\
\hline Stock & 0.29 & 0 & 0.45 & 0 & 0 & 1 & 1 & 6,004 \\
\hline Tender & 0.19 & 0 & 0.39 & 0 & 0 & 0 & 1 & 6,004 \\
\hline Hostile & 0.02 & 0 & 0.13 & 0 & 0 & 0 & 1 & 6,004 \\
\hline Conglomerate & 0.47 & 0 & 0.50 & 0 & 0 & 1 & 1 & 6,004 \\
\hline Competed & 0.10 & 0 & 0.30 & 0 & 0 & 0 & 1 & 6,004 \\
\hline $\log$ (Number of Deals) & 2.83 & 2.89 & 1.27 & 0.00 & 1.95 & 3.93 & 4.93 & 6,004 \\
\hline Completed & 0.75 & 1 & 0.43 & 0 & 0 & 1 & 1 & 6,004 \\
\hline \multicolumn{9}{|l|}{ Gambling propensity } \\
\hline CPRATIO & 1.58 & 0.65 & 1.64 & 0.05 & 0.62 & 2.29 & 6.60 & 5,774 \\
\hline CFNAI & 0.04 & 0.19 & 0.50 & -1.66 & -0.21 & 0.36 & 0.80 & 6,004 \\
\hline CEO Age & 55.02 & 55 & 6.72 & 35 & 51 & 59 & 87 & 1,762 \\
\hline \multicolumn{9}{|c|}{ Managerial discretion variables } \\
\hline GIM-Index & 9.42 & 9 & 2.67 & 4 & 7 & 11 & 15 & 1,430 \\
\hline PM Competition & 0.15 & 0.11 & 0.14 & 0.02 & 0.06 & 0.20 & 0.85 & 5,644 \\
\hline CEO Ownership & 1.88 & 0.00 & 5.73 & 0.00 & 0.00 & 0.90 & 48.70 & 1,860 \\
\hline \multicolumn{9}{|c|}{ Variables indicating loss space } \\
\hline RET12 & 0.08 & 0.01 & 0.55 & -0.87 & -0.25 & 0.32 & 2.47 & 6,004 \\
\hline Diff52 & 0.45 & 0.18 & 0.73 & 0.00 & 0.06 & 0.51 & 4.69 & 3,515 \\
\hline Negative Net Income & 0.15 & 0 & 0.35 & 0 & 0 & 0 & 1 & 3,669 \\
\hline
\end{tabular}




\section{TABLE III}

\section{Offer price premium}

This table presents results for OLS regressions of the offer price premium on lottery measures and control variables. The offer price premium is defined as the bid price over the target's stock price 4 weeks before the takeover announcement minus 1 . The lottery index LIDX measures the similarity of the stock of the target with salient features of attractive gambles. LIDX increases in the attractiveness of the target as a gamble. The constituents of LIDX are the price of the target's stock (Price), expected idiosyncratic skewness (EISKEW), and idiosyncratic volatility (IVOLA), all measured at the end of the second month prior to the month of the announcement. All variables are defined in Appendix Table A.1. The t-statistics for the coefficient estimates are reported in small font size below the estimates. Standard errors are clustered by announcement month. 
TABLE III (Continued)

\section{Offer price premium}

\begin{tabular}{|c|c|c|c|c|c|c|c|c|}
\hline \multirow[t]{2}{*}{ Dependent var.: } & \multicolumn{8}{|c|}{ "Offer Price Premium } \\
\hline & (1) & (2) & (3) & (4) & $(5)$ & (6) & (7) & (8) \\
\hline \multirow[t]{2}{*}{ LIDX } & 31.482 & & & & 27.775 & & & \\
\hline & 7.25 & & & & 5.96 & & & \\
\hline \multirow[t]{2}{*}{ EISKEW } & & 12.285 & & & & 10.174 & & \\
\hline & & 5.37 & & & & 4.49 & & \\
\hline \multirow[t]{2}{*}{ IVOLA } & & & 2.601 & & & & 2.042 & \\
\hline & & & 4.40 & & & & 3.38 & \\
\hline \multirow[t]{2}{*}{ Price } & & & & -0.263 & & & & -0.211 \\
\hline & & & & -3.57 & & & & -2.92 \\
\hline \multirow[t]{2}{*}{ Acquiror ROA } & 18.062 & 21.397 & 18.981 & 14.668 & 15.262 & 16.765 & 14.298 & 11.495 \\
\hline & 1.88 & 2.18 & 1.92 & 1.51 & 1.59 & 1.70 & 1.45 & 1.19 \\
\hline \multirow[t]{2}{*}{ Acquiror BM Ratio } & -2.776 & -2.953 & -2.693 & -2.868 & -2.639 & -2.831 & -2.644 & -2.725 \\
\hline & -3.12 & -3.29 & -3.02 & -3.14 & -3.00 & -3.19 & -3.00 & -3.03 \\
\hline \multirow[t]{2}{*}{ Acquiror MCAP } & 4.312 & 4.127 & 4.189 & 4.456 & 4.206 & 4.010 & 4.041 & 4.265 \\
\hline & 6.70 & 6.40 & 6.42 & 6.86 & 6.44 & 6.09 & 6.09 & 6.49 \\
\hline \multirow[t]{2}{*}{ Target ROA } & 2.271 & 0.224 & -0.683 & -5.354 & 3.032 & 1.384 & 0.102 & -2.961 \\
\hline & 0.28 & 0.03 & -0.09 & -0.69 & 0.37 & 0.18 & 0.01 & -0.38 \\
\hline \multirow[t]{2}{*}{ Target BM Ratio } & 9.963 & 8.264 & 9.760 & 8.711 & 9.435 & 8.002 & 9.097 & 8.486 \\
\hline & 4.97 & 4.29 & 4.81 & 4.39 & 4.61 & 4.06 & 4.44 & 4.21 \\
\hline \multirow[t]{2}{*}{ Target MCAP } & -4.352 & -5.163 & -5.773 & -5.794 & -4.814 & -5.564 & -6.123 & -6.108 \\
\hline & -5.26 & -6.09 & -7.02 & -7.02 & -5.41 & -6.28 & -7.11 & -7.16 \\
\hline \multirow[t]{2}{*}{ Relative Size } & 5.663 & 5.605 & 5.602 & 5.962 & 5.123 & 5.043 & 5.016 & 5.302 \\
\hline & 5.69 & 5.54 & 5.54 & 5.80 & 5.37 & 5.19 & 5.17 & 5.43 \\
\hline \multirow[t]{2}{*}{ Cash } & & & & & -1.232 & -0.281 & -0.573 & -0.591 \\
\hline & & & & & -0.60 & -0.14 & -0.28 & -0.29 \\
\hline \multirow[t]{2}{*}{ Stock } & & & & & 0.932 & 0.699 & -0.066 & 0.736 \\
\hline & & & & & 0.63 & 0.48 & -0.05 & 0.50 \\
\hline \multirow[t]{2}{*}{ Tender } & & & & & 11.189 & 10.411 & 10.668 & 10.666 \\
\hline & & & & & 4.93 & 4.64 & 4.72 & 4.74 \\
\hline \multirow[t]{2}{*}{ Hostile } & & & & & 6.935 & 6.214 & 6.144 & 5.362 \\
\hline & & & & & 1.74 & 1.55 & 1.53 & 1.36 \\
\hline \multirow[t]{2}{*}{ Conglomerate } & & & & & -0.772 & -0.545 & -0.451 & -0.268 \\
\hline & & & & & -0.50 & -0.36 & -0.29 & -0.17 \\
\hline \multirow[t]{2}{*}{ Competed } & & & & & 15.815 & 15.421 & 16.142 & 16.395 \\
\hline & & & & & 5.07 & 4.92 & 5.21 & 5.29 \\
\hline \multirow[t]{2}{*}{ New Economy } & & & & & 5.565 & 7.880 & 7.268 & 8.926 \\
\hline & & & & & 2.52 & 3.71 & 3.28 & 3.86 \\
\hline \multirow[t]{2}{*}{$\log ($ Number of Deals $)$} & & & & & 0.453 & -0.314 & -0.083 & -0.175 \\
\hline & & & & & 0.73 & -0.51 & -0.13 & -0.28 \\
\hline Adjusted $R^{2}$ & 0.087 & 0.085 & 0.079 & 0.076 & 0.110 & 0.109 & 0.104 & 0.103 \\
\hline Number of observations & 3,276 & 3,276 & 3,276 & 3,276 & 3,275 & 3,275 & 3,275 & 3,275 \\
\hline
\end{tabular}




\section{TABLE IV}

\section{Synergies}

This table presents results for OLS regressions of synergies on lottery measures and control variables. Synergies are defined following Bradley, Desai, and Kim (1988) as weighted sum (by market capitalization) of the bidder and target cumulative abnormal announcement returns. Bidder and target announcement returns are computed using the $[-1,+1]$ event window and a market model estimated over days [-280,-31]. The lottery index LIDX measures the similarity of the stock of the target with salient features of attractive gambles. LIDX increases in the attractiveness of the target as a gamble. The constituents of LIDX are the price of the target's stock (Price), expected idiosyncratic skewness (EISKEW), and idiosyncratic volatility (IVOLA), all measured at the end of the second month prior to the month of the announcement. All variables are defined in Appendix Table A.1. The t-statistics for the coefficient estimates are reported in small font size below the estimates. Standard errors are clustered by announcement month. 


\section{TABLE IV (Continued)}

\section{Synergies}

\begin{tabular}{|c|c|c|c|c|c|c|c|c|}
\hline \multirow[t]{2}{*}{ Dependent var.: } & \multicolumn{8}{|c|}{ Synergy $[-1,+1]$} \\
\hline & (1) & $(2)$ & (3) & (4) & (5) & (6) & (7) & $(8)$ \\
\hline \multirow[t]{2}{*}{ LIDX } & -1.764 & & & & -2.400 & & & \\
\hline & -2.72 & & & & -3.63 & & & \\
\hline \multirow[t]{2}{*}{ EISKEW } & & -0.982 & & & & -0.966 & & \\
\hline & & -2.80 & & & & -2.99 & & \\
\hline \multirow[t]{2}{*}{ IVOLA } & & & -0.476 & & & & -0.440 & \\
\hline & & & -5.50 & & & & -5.12 & \\
\hline \multirow[t]{2}{*}{ Price } & & & & 0.011 & & & & 0.020 \\
\hline & & & & 1.14 & & & & 2.03 \\
\hline \multirow[t]{2}{*}{ Acquiror ROA } & 2.923 & 2.582 & 2.260 & 3.112 & 0.579 & 0.414 & 0.168 & 0.886 \\
\hline & 1.77 & 1.54 & 1.37 & 1.88 & 0.36 & 0.25 & 0.10 & 0.55 \\
\hline \multirow[t]{2}{*}{ Acquiror BM Ratio } & 1.013 & 1.029 & 1.005 & 1.018 & 0.795 & 0.813 & 0.798 & 0.805 \\
\hline & 5.15 & 5.25 & 5.19 & 5.16 & 4.19 & 4.31 & 4.26 & 4.24 \\
\hline \multirow[t]{2}{*}{ Acquiror MCAP } & -0.366 & -0.352 & -0.341 & -0.372 & -0.504 & -0.487 & -0.476 & -0.510 \\
\hline & -3.75 & -3.59 & -3.48 & -3.81 & -5.34 & -5.17 & -5.04 & -5.37 \\
\hline \multirow[t]{2}{*}{ Target ROA } & 0.410 & 0.316 & -0.378 & 0.869 & -0.117 & -0.037 & -0.505 & 0.373 \\
\hline & 0.41 & 0.32 & -0.39 & 0.89 & -0.12 & -0.04 & -0.53 & 0.40 \\
\hline \multirow[t]{2}{*}{ Target BM Ratio } & 0.399 & 0.504 & 0.254 & 0.471 & 0.061 & 0.190 & -0.006 & 0.142 \\
\hline & 1.42 & 1.81 & 0.92 & 1.67 & 0.21 & 0.68 & -0.02 & 0.50 \\
\hline \multirow[t]{2}{*}{ Target MCAP } & -0.141 & -0.142 & -0.243 & -0.042 & -0.095 & -0.041 & -0.123 & 0.010 \\
\hline & -1.00 & -1.02 & -1.82 & -0.32 & -0.69 & -0.31 & -0.93 & 0.07 \\
\hline \multirow[t]{2}{*}{ Relative Size } & 0.819 & 0.824 & 0.843 & 0.805 & 0.765 & 0.770 & 0.788 & 0.748 \\
\hline & 4.31 & 4.33 & 4.48 & 4.24 & 4.20 & 4.22 & 4.35 & 4.10 \\
\hline \multirow[t]{2}{*}{ Cash } & & & & & 1.094 & 1.010 & 1.040 & 1.042 \\
\hline & & & & & 3.71 & 3.45 & 3.57 & 3.54 \\
\hline \multirow[t]{2}{*}{ Stock } & & & & & -1.399 & -1.386 & -1.257 & -1.388 \\
\hline & & & & & -4.67 & -4.61 & -4.26 & -4.60 \\
\hline \multirow[t]{2}{*}{ Tender } & & & & & 1.596 & 1.664 & 1.654 & 1.633 \\
\hline & & & & & 4.40 & 4.60 & 4.55 & 4.54 \\
\hline \multirow[t]{2}{*}{ Hostile } & & & & & 2.318 & 2.370 & 2.329 & 2.467 \\
\hline & & & & & 3.01 & 3.09 & 3.07 & 3.23 \\
\hline \multirow[t]{2}{*}{ Conglomerate } & & & & & -0.389 & -0.402 & -0.380 & -0.431 \\
\hline & & & & & -1.69 & -1.74 & -1.64 & -1.88 \\
\hline \multirow[t]{2}{*}{ Competed } & & & & & -0.952 & -0.912 & -0.993 & -1.004 \\
\hline & & & & & -2.09 & -2.00 & -2.18 & -2.19 \\
\hline \multirow[t]{2}{*}{ New Economy } & & & & & -0.928 & -1.103 & -0.697 & -1.199 \\
\hline & & & & & -2.44 & -3.10 & -1.93 & -3.15 \\
\hline \multirow[t]{2}{*}{$\log$ (Number of Deals) } & & & & & -0.315 & -0.252 & -0.321 & -0.264 \\
\hline & & & & & -3.08 & -2.56 & -3.10 & -2.67 \\
\hline Adjusted $R^{2}$ & 0.092 & 0.094 & 0.102 & 0.091 & 0.138 & 0.138 & 0.143 & 0.136 \\
\hline Number of observations & 3,337 & 3,337 & 3,337 & 3,337 & 3,336 & 3,336 & 3,336 & 3,336 \\
\hline
\end{tabular}




\section{TABLE V}

\section{Announcement returns}

This table presents results for OLS regressions of acquiror announcement returns (ACAR $[-1,+1])$ in Panel A and target announcement returns (TCAR $[-1,+1]$ ) in Panel B on lottery measures and control variables. Bidder and target cumulative abnormal announcement returns are computed using the $[-1,+1]$ event window and a market model estimated over days $[-280,-31]$. The lottery index LIDX measures the similarity of the stock of the target with salient features of attractive gambles. LIDX increases in the attractiveness of the target as a gamble. The constituents of LIDX are the price of the target's stock (Price), expected idiosyncratic skewness (EISKEW), and idiosyncratic volatility (IVOLA), all measured at the end of the second month prior to the month of the announcement. All variables are defined in Appendix Table A.1. The t-statistics for the coefficient estimates are reported in small font size below the estimates. Standard errors are clustered by announcement month. 


\section{TABLE V (Continued)}

\section{Announcement returns}

Panel A: Acquiror announcement returns

\begin{tabular}{|c|c|c|c|c|c|c|c|c|}
\hline \multirow[t]{2}{*}{ Dependent var.: } & \multicolumn{8}{|c|}{$\operatorname{ACAR}[-1,+1]$} \\
\hline & (1) & $(2)$ & $(3)$ & $(4)$ & $(5)$ & (6) & (7) & (8) \\
\hline \multirow[t]{2}{*}{ LIDX } & -2.668 & & & & -3.392 & & & \\
\hline & -4.17 & & & & -4.98 & & & \\
\hline \multirow[t]{2}{*}{ EISKEW } & & -1.461 & & & & -1.414 & & \\
\hline & & -4.48 & & & & -4.38 & & \\
\hline \multirow[t]{2}{*}{ IVOLA } & & & -0.463 & & & & -0.426 & \\
\hline & & & -5.72 & & & & -5.04 & \\
\hline \multirow[t]{2}{*}{ Price } & & & & 0.024 & & & & 0.030 \\
\hline & & & & 1.98 & & & & 2.46 \\
\hline \multirow[t]{2}{*}{ Acquiror ROA } & 1.775 & 1.265 & 1.259 & 2.041 & -0.194 & -0.463 & -0.399 & 0.235 \\
\hline & 0.93 & 0.66 & 0.65 & 1.06 & -0.10 & -0.24 & -0.21 & 0.12 \\
\hline \multirow[t]{2}{*}{ Acquiror BM Ratio } & 0.600 & 0.623 & 0.591 & 0.612 & 0.421 & 0.447 & 0.424 & 0.436 \\
\hline & 3.74 & 3.85 & 3.71 & 3.79 & 2.61 & 2.75 & 2.63 & 2.69 \\
\hline \multirow{2}{*}{ Acquiror MCAP } & 0.428 & 0.450 & 0.452 & 0.416 & 0.325 & 0.349 & 0.354 & 0.315 \\
\hline & 4.37 & 4.60 & 4.61 & 4.23 & 3.25 & 3.53 & 3.57 & 3.14 \\
\hline \multirow[t]{2}{*}{ Target ROA } & -1.127 & -1.250 & -1.576 & -0.504 & -1.784 & -1.700 & -1.859 & -1.101 \\
\hline & -1.29 & -1.44 & -1.80 & -0.59 & -2.02 & -1.96 & -2.10 & -1.28 \\
\hline \multirow[t]{2}{*}{ Target BM Ratio } & 0.074 & 0.231 & -0.025 & 0.177 & -0.219 & -0.036 & -0.244 & -0.106 \\
\hline & 0.26 & 0.81 & -0.09 & 0.61 & -0.75 & -0.12 & -0.84 & -0.36 \\
\hline \multirow[t]{2}{*}{ Target MCAP } & -1.128 & -1.125 & -1.140 & -1.011 & -1.090 & -1.022 & -1.025 & -0.949 \\
\hline & -8.02 & -8.30 & -8.67 & -7.58 & -7.50 & -7.27 & -7.52 & -6.88 \\
\hline \multirow[t]{2}{*}{ Relative Size } & -0.148 & -0.141 & -0.129 & -0.175 & -0.191 & -0.183 & -0.168 & -0.216 \\
\hline & -0.85 & -0.80 & -0.74 & -0.99 & -1.13 & -1.07 & -1.00 & -1.27 \\
\hline \multirow[t]{2}{*}{ Cash } & & & & & 1.286 & 1.165 & 1.210 & 1.212 \\
\hline & & & & & 4.36 & 3.99 & 4.14 & 4.14 \\
\hline \multirow[t]{2}{*}{ Stock } & & & & & -0.927 & -0.909 & -0.766 & -0.910 \\
\hline & & & & & -3.15 & -3.06 & -2.62 & -3.07 \\
\hline \multirow[t]{2}{*}{ Tender } & & & & & 0.590 & 0.688 & 0.662 & 0.647 \\
\hline & & & & & 1.74 & 2.05 & 1.95 & 1.93 \\
\hline \multirow[t]{2}{*}{ Hostile } & & & & & 0.124 & 0.201 & 0.187 & 0.336 \\
\hline & & & & & 0.16 & 0.26 & 0.25 & 0.45 \\
\hline \multirow[t]{2}{*}{ Conglomerate } & & & & & -0.114 & -0.134 & -0.132 & -0.175 \\
\hline & & & & & -0.43 & -0.51 & -0.50 & -0.67 \\
\hline \multirow[t]{2}{*}{ Competed } & & & & & -0.460 & -0.399 & -0.508 & -0.538 \\
\hline & & & & & -0.95 & -0.82 & -1.05 & -1.11 \\
\hline \multirow[t]{2}{*}{ New Economy } & & & & & -0.941 & -1.181 & -0.896 & -1.317 \\
\hline & & & & & -2.47 & -3.24 & -2.41 & -3.47 \\
\hline \multirow[t]{2}{*}{$\log ($ Number of Deals $)$} & & & & & -0.427 & -0.339 & -0.395 & -0.356 \\
\hline & & & & & -3.87 & -3.21 & -3.62 & -3.41 \\
\hline Adjusted $R^{2}$ & 0.042 & 0.045 & 0.048 & 0.039 & 0.069 & 0.071 & 0.072 & 0.066 \\
\hline Number of observations & 3,361 & 3,361 & 3,361 & 3,361 & 3,360 & 3,360 & 3,360 & 3,360 \\
\hline
\end{tabular}




\section{TABLE V (Continued)}

\section{Announcement returns}

Panel B: Target announcement returns

\begin{tabular}{|c|c|c|c|c|c|c|c|c|}
\hline \multirow[t]{2}{*}{ Dependent var. } & \multicolumn{8}{|c|}{ TCAR $[-1,+1]$} \\
\hline & (1) & $(2)$ & (3) & $(4)$ & $(5)$ & (6) & (7) & (8) \\
\hline \multirow[t]{2}{*}{ LIDX } & 14.335 & & & & 11.464 & & & \\
\hline & 6.13 & & & & 4.45 & & & \\
\hline \multirow[t]{2}{*}{ EISKEW } & & 6.234 & & & & 5.559 & & \\
\hline & & 5.18 & & & & 4.64 & & \\
\hline \multirow[t]{2}{*}{ IVOLA } & & & 0.564 & & & & 0.299 & \\
\hline & & & 1.96 & & & & 1.00 & \\
\hline \multirow[t]{2}{*}{ Price } & & & & -0.170 & & & & -0.124 \\
\hline & & & & -4.97 & & & & -3.84 \\
\hline \multirow[t]{2}{*}{ Acquiror ROA } & 11.086 & 13.006 & 10.314 & 9.611 & 6.242 & 7.722 & 4.768 & 4.820 \\
\hline & 3.00 & 3.46 & 2.73 & 2.61 & 1.67 & 2.05 & 1.26 & 1.30 \\
\hline \multirow[t]{2}{*}{ Acquiror BM Ratio } & 1.304 & 1.212 & 1.323 & 1.226 & 0.703 & 0.601 & 0.699 & 0.647 \\
\hline & 2.80 & 2.59 & 2.86 & 2.67 & 1.51 & 1.28 & 1.50 & 1.39 \\
\hline \multirow[t]{2}{*}{ Acquiror MCAP } & 3.322 & 3.225 & 3.301 & 3.413 & 2.834 & 2.736 & 2.793 & 2.883 \\
\hline & 9.81 & 9.53 & 9.64 & 10.07 & 8.24 & 7.99 & 8.05 & 8.38 \\
\hline \multirow[t]{2}{*}{ Target ROA } & 0.514 & 0.024 & -2.620 & -2.363 & 0.179 & 0.338 & -2.312 & -1.908 \\
\hline & 0.17 & 0.01 & -0.84 & -0.76 & 0.06 & 0.11 & -0.76 & -0.62 \\
\hline \multirow[t]{2}{*}{ Target BM Ratio } & 3.141 & 2.351 & 2.770 & 2.595 & 2.983 & 2.339 & 2.657 & 2.604 \\
\hline & 3.49 & 2.77 & 3.00 & 2.98 & 3.24 & 2.65 & 2.84 & 2.89 \\
\hline \multirow[t]{2}{*}{ Target MCAP } & -2.630 & -2.904 & -3.608 & -3.036 & -2.418 & -2.522 & -3.242 & -2.774 \\
\hline & -6.04 & -6.91 & -8.56 & -7.76 & -5.39 & -5.93 & -7.50 & -6.86 \\
\hline \multirow[t]{2}{*}{ Relative Size } & 0.337 & 0.301 & 0.359 & 0.518 & 0.318 & 0.273 & 0.305 & 0.431 \\
\hline & 0.84 & 0.74 & 0.89 & 1.30 & 0.79 & 0.67 & 0.76 & 1.07 \\
\hline \multirow[t]{2}{*}{ Cash } & & & & & 3.034 & 3.459 & 3.306 & 3.295 \\
\hline & & & & & 2.64 & 3.00 & 2.85 & 2.86 \\
\hline \multirow[t]{2}{*}{ Stock } & & & & & -1.848 & -1.885 & -2.163 & -1.853 \\
\hline & & & & & -2.05 & -2.10 & -2.40 & -2.07 \\
\hline \multirow[t]{2}{*}{ Tender } & & & & & 6.928 & 6.575 & 6.749 & 6.698 \\
\hline & & & & & 5.41 & 5.18 & 5.28 & 5.27 \\
\hline \multirow[t]{2}{*}{ Hostile } & & & & & 7.845 & 7.658 & 7.299 & 7.131 \\
\hline & & & & & 3.88 & 3.78 & 3.60 & 3.51 \\
\hline \multirow[t]{2}{*}{ Conglomerate } & & & & & -0.421 & -0.384 & -0.201 & -0.241 \\
\hline & & & & & -0.52 & -0.47 & -0.24 & -0.29 \\
\hline \multirow[t]{2}{*}{ Competed } & & & & & -5.560 & -5.821 & -5.453 & -5.272 \\
\hline & & & & & -4.88 & -5.08 & -4.82 & -4.67 \\
\hline \multirow[t]{2}{*}{ New Economy } & & & & & 0.987 & 1.593 & 2.499 & 2.134 \\
\hline & & & & & 0.82 & 1.38 & 2.13 & 1.89 \\
\hline \multirow[t]{2}{*}{$\log$ (Number of Deals) } & & & & & -0.086 & -0.369 & -0.423 & -0.288 \\
\hline & & & & & -0.26 & -1.13 & -1.26 & -0.87 \\
\hline Adjusted $R^{2}$ & 0.093 & 0.095 & 0.082 & 0.090 & 0.123 & 0.127 & 0.117 & 0.121 \\
\hline Number of observations & 3,381 & 3,381 & 3,381 & 3,381 & 3,380 & 3,380 & 3,380 & 3,380 \\
\hline
\end{tabular}




\section{TABLE VI}

\section{Robustness checks}

This table presents robustness checks. It reports the coefficient estimates of LIDX and its t-statistic as well as the number of observations below the estimates. The baseline regression is model (5) from Tables III to V. In Panel A the baseline regression is rerun for three different LIDX variables based on alternative prediction periods of EISKEW. Panel A also reports the results for different event windows. In Panel B the baseline regression is rerun for different subsamples: (i) only deals with acquirors above or below the median acquiror size in the respective year of the takeover announcement, (ii) only deals with targets above or below the median target size in the respective year of the takeover announcement, (iii) only deals announced when investor sentiment is above or below the median investor sentiment over our sample period; investor sentiment data is taken from Jeffrey Wurgler's website and lagged by 2 months, (iv) only deals with targets above or below the median target Altman's (1968) Z-Score over our sample period, (v) only deals with targets above or below the median target CHS-Score over our sample period; CHS-Score is a measure of bankruptcy likelihood estimated using the regression coefficients from the benchmark model in Campbell, Hilscher, and Szilagyi (2008) (Table III, Model 2, failure sample 1963-2003), (vi) only deals from one of the three subperiods 1986 to 1993, 1994 to 2001, and 2002 to 2008. In Panel C the baseline regression is rerun including an number of additional controls and modifications: (i) year fixed effects, (ii) year and industry fixed effects (2-digit SIC), (iii) uses an alternative lottery index with idiosyncratic skewness from a three factor Fama-French model instead of EISKEW, (iv) include operating cash flow over total assets and total debt over firm market value of the acquiror at the last fiscal year end before the takeover announcement, excluding financial firms from the sample, (v) include Amihud's (2002) measure of liquidity for the target estimated over the month $t-2$, (vi) control for systematic risk and coskewness, each estimated for a 3-year period from the beginning of month $t-49$ until the end of month $t-2$, (vii) target Altman's (1968) Z-Score, (viii) acquiror Altman's (1968) Z-Score, (ix) confident CEO dummy, which equals one if the acquiror CEO holds vested options that are at least $67 \%$ in the money at the fiscal year end before the takeover announcement; average moneyness of the CEOs option portfolio is estimated following Hirshleifer, Low, and Teoh (2010), (x) vega of the acquiror CEO's option package estimated following Chava and Purnanandam (2009), (xi) average percentage of acquiror CEO compensation in options over the three year period prior to the acquisition announcement, (xii) difference to the target's 52-week high, (xiii) standard deviation of financial analysts forecasts on the targets one-year-ahead earnings, and (xiv) change in the breadth of mutual fund ownership (see Chatterjee, John, and Yan (2009)). Panel $\mathrm{C}$ also reports the results of the baseline regression for a number of different specifications: (xv) only completed deals are included, (xvi) all deals with new economy targets (SIC codes 3570 to $3579,3661,3674,5045,5961$, or 7370 to 7379 ) are excluded, (xvii) only deals with relative size larger 1\%, (xvii) only deals with targets having a stock price above $\$ 5$ at the end of end of month $t-2$ are included, (xix) none of the dependent and independent variables is winsorized, (xx) median instead of OLS regression model is used, (xxi) dependent variables are expressed in US\$ instead of percentage terms. Standard errors are clustered by announcement month for all OLS regressions. 


\section{TABLE VI (Continued)}

\section{Robustness checks}

Panel A: Alternative estimation periods

\begin{tabular}{|c|c|c|c|c|}
\hline \multirow[t]{2}{*}{ Variable } & $\mathrm{OPP}$ & Synergy & ACAR & TCAR \\
\hline & $(1)$ & $(2)$ & $(3)$ & (4) \\
\hline \multirow[t]{3}{*}{ Baseline } & 27.775 & -2.400 & -3.392 & 11.464 \\
\hline & 5.96 & -3.63 & -4.98 & 4.45 \\
\hline & 3,275 & 3,336 & 3,360 & 3,380 \\
\hline \multicolumn{5}{|c|}{ Alternative EISKEW prediction periods } \\
\hline \multirow[t]{3}{*}{2 years } & 31.693 & -1.724 & -2.860 & 13.604 \\
\hline & 6.86 & -2.63 & -4.23 & 5.41 \\
\hline & 3,361 & 3,509 & 3,535 & 3,557 \\
\hline \multirow[t]{3}{*}{3 years } & 27.712 & -1.890 & -2.980 & 11.903 \\
\hline & 5.93 & -2.78 & -4.33 & 4.70 \\
\hline & 3,357 & 3,424 & 3,448 & 3,470 \\
\hline \multirow[t]{3}{*}{5 years } & 26.452 & -2.195 & -3.082 & 12.029 \\
\hline & 5.73 & -3.19 & -4.31 & 4.55 \\
\hline & 3,191 & 3,252 & 3,276 & 3,296 \\
\hline \multicolumn{5}{|c|}{ Alternative event windows } \\
\hline \multirow[t]{3}{*}[-2,+2]{} & n.a. & -1.901 & -3.058 & 12.292 \\
\hline & & -2.25 & -3.72 & 4.77 \\
\hline & & 3,336 & 3,360 & 3,380 \\
\hline \multirow[t]{3}{*}[-3,+3]{} & n.a. & -1.931 & -2.738 & 11.985 \\
\hline & & -2.19 & -3.17 & 4.67 \\
\hline & & 3,335 & 3,360 & 3,380 \\
\hline \multirow[t]{3}{*}[-5,+5]{} & n.a. & -3.067 & -3.143 & 10.655 \\
\hline & & -2.48 & -2.44 & 3.59 \\
\hline & & 3,336 & 3,360 & 3,380 \\
\hline \multirow[t]{3}{*}[-20,+20]{} & n.a. & -3.801 & -4.304 & 23.469 \\
\hline & & -1.52 & -1.71 & 6.07 \\
\hline & & 3,336 & 3,360 & 3,380 \\
\hline
\end{tabular}




\section{TABLE VI (Continued)}

\section{Robustness checks}

Panel B: Subsamples

\begin{tabular}{|c|c|c|c|c|}
\hline \multirow[t]{2}{*}{ Variable } & $\overline{\mathrm{OPP}}$ & Synergy & ACAR & TCAR \\
\hline & (1) & (2) & (3) & (4) \\
\hline \multirow[t]{3}{*}{ Baseline } & 27.775 & -2.400 & -3.392 & 11.464 \\
\hline & 5.96 & -3.63 & -4.98 & 4.45 \\
\hline & 3,275 & 3,336 & 3,360 & 3,380 \\
\hline \multirow[t]{3}{*}{ Large acquiror } & 31.524 & -1.757 & -1.779 & 16.720 \\
\hline & 4.31 & -2.03 & -1.89 & 3.81 \\
\hline & 1,646 & 1,680 & 1,695 & 1,699 \\
\hline \multirow[t]{3}{*}{ Small acquiror } & 29.408 & -3.568 & -4.986 & 9.404 \\
\hline & 4.56 & -3.25 & -4.34 & 2.85 \\
\hline & 1,629 & 1,656 & 1,665 & 1,681 \\
\hline \multirow[t]{3}{*}{ Large target } & 22.064 & -2.883 & -3.396 & 8.324 \\
\hline & 3.13 & -2.73 & -3.18 & 2.53 \\
\hline & 1,820 & 1,845 & 1,861 & 1,874 \\
\hline \multirow[t]{3}{*}{ Small target } & 37.347 & -2.208 & -3.665 & 15.939 \\
\hline & 5.23 & -2.26 & -3.79 & 3.99 \\
\hline & 1,455 & 1,491 & 1,499 & 1,506 \\
\hline \multirow[t]{3}{*}{ High sentiment } & 25.693 & -4.290 & -4.776 & 6.748 \\
\hline & 3.13 & -4.17 & -4.58 & 1.57 \\
\hline & 1,529 & 1,548 & 1,562 & 1,570 \\
\hline \multirow[t]{3}{*}{ Low sentiment } & 33.250 & -1.535 & -2.755 & 11.881 \\
\hline & 5.55 & -1.49 & -2.69 & 3.59 \\
\hline & 1,380 & 1,424 & 1,433 & 1,443 \\
\hline \multirow[t]{3}{*}{ High Z-Score } & 22.147 & -1.591 & -1.939 & 6.735 \\
\hline & 3.42 & -1.70 & -2.00 & 1.97 \\
\hline & 1,657 & 1,709 & 1,719 & 1,724 \\
\hline \multirow[t]{3}{*}{ Low Z-Score } & 33.737 & -2.792 & -3.884 & 16.158 \\
\hline & 4.79 & -2.60 & -3.46 & 4.12 \\
\hline & 1,618 & 1,627 & 1,641 & 1,656 \\
\hline \multirow[t]{3}{*}{ High CHS-Score } & 29.850 & -2.288 & -3.068 & 13.011 \\
\hline & 3.69 & -2.04 & -2.72 & 2.99 \\
\hline & 1,603 & 1,632 & 1,643 & 1,649 \\
\hline \multirow[t]{3}{*}{ Low CHS-Score } & 14.476 & -2.276 & -3.665 & 6.286 \\
\hline & 2.75 & -2.29 & -3.19 & 2.00 \\
\hline & 1,579 & 1,593 & 1,606 & 1,620 \\
\hline \multirow[t]{3}{*}{ Years 1987-1994 } & 43.247 & 1.807 & -0.230 & 18.783 \\
\hline & 3.47 & 1.02 & -0.15 & 2.93 \\
\hline & 570 & 636 & 638 & 641 \\
\hline \multirow[t]{3}{*}{ Years 1995-2001 } & 31.260 & -3.489 & -3.821 & 8.418 \\
\hline & 4.33 & -3.46 & -3.69 & 2.14 \\
\hline & 1,795 & 1,798 & 1,818 & 1,828 \\
\hline \multirow[t]{3}{*}{ Years 2002-2008 } & 36.036 & -2.988 & -5.232 & 15.383 \\
\hline & 5.44 & -2.48 & -3.80 & 3.60 \\
\hline & 910 & 902 & 904 & 911 \\
\hline
\end{tabular}




\section{TABLE VI (Continued)}

\section{Robustness checks}

Panel C: Alternative regression specifications

\begin{tabular}{|c|c|c|c|c|}
\hline \multirow[t]{2}{*}{ Variable } & $\mathrm{OPP}$ & Synergy & ACAR & TCAR \\
\hline & (1) & $(2)$ & (3) & (4) \\
\hline \multirow[t]{3}{*}{ Baseline } & 27.775 & -2.400 & -3.392 & 11.464 \\
\hline & 5.96 & -3.63 & -4.98 & 4.45 \\
\hline & 3,275 & 3,336 & 3,360 & 3,380 \\
\hline \multirow[t]{3}{*}{ Year dummies } & 33.756 & -2.868 & -3.496 & 10.428 \\
\hline & 6.87 & -3.95 & -4.77 & 3.91 \\
\hline & 3,275 & 3,336 & 3,360 & 3,380 \\
\hline \multirow[t]{3}{*}{ Year and industry dummies } & 31.630 & -3.706 & -3.615 & 6.774 \\
\hline & 5.69 & -4.54 & -4.46 & 2.39 \\
\hline & 3,275 & 3,336 & 3,360 & 3,380 \\
\hline Alternative lottery acquisition & 13.145 & -2.072 & -1.768 & -0.233 \\
\hline \multirow[t]{2}{*}{ measure } & 2.70 & -2.89 & -2.37 & -0.09 \\
\hline & 3,416 & 3,482 & 3,508 & 3,531 \\
\hline \multirow[t]{3}{*}{ Additional controls (no banks) } & 25.209 & -3.589 & -3.699 & 11.385 \\
\hline & 3.84 & -4.17 & -3.98 & 3.50 \\
\hline & 2,375 & 2,404 & 2,419 & 2,439 \\
\hline \multirow[t]{3}{*}{ Control for liquidity (Amihud) } & 26.051 & -2.422 & -3.302 & 10.652 \\
\hline & 5.60 & -3.64 & -4.82 & 4.14 \\
\hline & 3,274 & 3,335 & 3,359 & 3,379 \\
\hline Control for systematic risk & 26.154 & -1.532 & -2.424 & 12.611 \\
\hline \multirow[t]{2}{*}{ and systematic skewness } & 5.46 & -2.23 & -3.46 & 4.73 \\
\hline & 3,275 & 3,336 & 3,360 & 3,380 \\
\hline \multirow[t]{3}{*}{ Control for acquiror Z-Score } & 25.493 & -3.501 & -3.933 & 11.552 \\
\hline & 3.90 & -4.03 & -4.15 & 3.44 \\
\hline & 2,328 & 2,359 & 2,374 & 2,394 \\
\hline \multirow[t]{3}{*}{ Control for target Z-Score } & 29.626 & -3.620 & -4.050 & 10.977 \\
\hline & 5.22 & -4.19 & -4.35 & 3.28 \\
\hline & 2,382 & 2,413 & 2,427 & 2,447 \\
\hline \multirow[t]{3}{*}{ Control for overconfidence } & 16.704 & -3.186 & -3.249 & 7.121 \\
\hline & 2.03 & -3.26 & -3.13 & 1.80 \\
\hline & 1,437 & 1,468 & 1,480 & 1,480 \\
\hline \multirow[t]{3}{*}{ Control for CEO option vega } & 16.858 & -3.052 & -3.074 & 7.890 \\
\hline & 2.27 & -3.44 & -3.18 & 2.15 \\
\hline & 1,648 & 1,683 & 1,697 & 1,699 \\
\hline \multirow[t]{3}{*}{ Control for CEO \% options } & 18.305 & -2.950 & -2.974 & 8.216 \\
\hline & 2.55 & -3.47 & -3.19 & 2.27 \\
\hline & 1,713 & 1,747 & 1,762 & 1,765 \\
\hline
\end{tabular}




\section{TABLE VI (Continued)}

\section{Robustness checks}

Panel C: Alternative regression specifications (continued)

\begin{tabular}{|c|c|c|c|c|}
\hline \multirow[t]{2}{*}{ Variable } & OPP & Synergy & ACAR & TCAR \\
\hline & (1) & $(2)$ & $(3)$ & $(4)$ \\
\hline \multirow[t]{3}{*}{ Baseline } & 27.775 & -2.400 & -3.392 & 11.464 \\
\hline & 5.96 & -3.63 & -4.98 & 4.45 \\
\hline & 3,275 & 3,336 & 3,360 & 3,380 \\
\hline \multirow[t]{3}{*}{ Control for target Diff52 } & 18.545 & -1.418 & -2.357 & 7.703 \\
\hline & 3.94 & -2.02 & -3.18 & 3.10 \\
\hline & 3,275 & 3,336 & 3,360 & 3,380 \\
\hline \multirow{3}{*}{$\begin{array}{l}\text { Control for analyst forecast } \\
\text { dispersion }\end{array}$} & 17.987 & -3.862 & -5.212 & 8.833 \\
\hline & 3.17 & -4.15 & -5.07 & 2.92 \\
\hline & 2,197 & 2,227 & 2,244 & 2,258 \\
\hline \multirow{3}{*}{$\begin{array}{l}\text { Control for change in the breadth } \\
\text { of mutual fund ownership }\end{array}$} & 25.612 & -2.452 & -3.741 & 11.263 \\
\hline & 5.08 & -3.54 & -5.31 & 4.05 \\
\hline & 2,917 & 2,955 & 2,978 & 2,998 \\
\hline \multirow[t]{3}{*}{ Only completed deals } & 29.366 & -1.905 & -3.030 & 12.243 \\
\hline & 6.52 & -2.64 & -4.06 & 4.19 \\
\hline & 2,743 & 2,790 & 2,808 & 2,826 \\
\hline \multirow[t]{3}{*}{ Exclude new economy } & 23.503 & -1.365 & -2.688 & 13.112 \\
\hline & 4.54 & -1.95 & -3.77 & 4.74 \\
\hline & 2,674 & 2,736 & 2,756 & 2,770 \\
\hline \multirow[t]{3}{*}{ Relative size $>1 \%$} & 30.329 & -2.510 & -3.479 & 10.844 \\
\hline & 6.92 & -3.54 & -4.82 & 4.32 \\
\hline & 3,077 & 3,135 & 3,157 & 3,176 \\
\hline \multirow[t]{3}{*}{ Price above $\$ 5$} & 13.612 & -1.865 & -2.553 & 4.822 \\
\hline & 2.77 & -2.27 & -3.03 & 1.78 \\
\hline & 2,666 & 2,718 & 2,741 & 2,756 \\
\hline \multirow[t]{3}{*}{ No winsorization of variables } & 18.004 & -3.084 & -4.519 & 13.768 \\
\hline & 3.04 & -3.93 & -5.54 & 5.27 \\
\hline & 3,275 & 3,336 & 3,360 & 3,380 \\
\hline \multirow[t]{3}{*}{ Median regression } & 18.326 & -1.442 & -2.143 & 4.903 \\
\hline & 4.24 & -2.41 & -3.86 & 1.91 \\
\hline & 3,275 & 3,336 & 3,360 & 3,380 \\
\hline \multirow[t]{3}{*}{$\$$ CARs $[-1,+1]$} & n.a. & -94.642 & -227.531 & 114.143 \\
\hline & & -1.10 & -2.81 & 4.23 \\
\hline & & 3,336 & 3,336 & 3,380 \\
\hline
\end{tabular}




\section{TABLE VII}

\section{Relative lotteryness and lotteryness of the combined firm}

This table presents results on the relative lotteryness of target and acquiror, and on the impact of the target on the lotteryness of the combined firm. Panel A shows results, when we replace the target lottery index LIDX with the relative lottery index RLIDX. RLIDX is defined as the ratio of target lottery index and acquiror lottery index. The regressions in Panel A, are otherwise identical to the regressions in Tables III to V, specification (5). Panel B reports OLS regressions of acquiror announcement returns (ACAR $[-1,+1]$ ) and Synergy $[-1,+1]$ on LIDX and control variables for a subsample of large, non-diversifying deals. The baseline regression is specification (5) from Tables IV and V, Panel A. The baseline regression is rerun for 4 different subsamples. Large \& Non-Div. denotes the subgroup of deals in which the deal size relative to the acquiror size is above the median in a given year, and in which both target and acquiror are in the same 2-digit SIC industry. Large \& Corr. denotes the subgroup of deals in which the deal size relative to the acquiror size is above the median in a given year, and the stock price correlation between target and acquiror stock, measured over days $[-280,-31]$ prior to the announcement is above the median correlation. The table reports the coefficient estimates of LIDX and its t-statistic as well as the number of observations in small font size below the estimates. The table also reports the difference between the coefficients on LIDX in the two subsamples and below the t-statistic from a Wald-test of equality of coefficients in small font size. See Appendix Table A.1 for a detailed overview of variable definitions. Standard errors are clustered by announcement month.

Panel A: Relative Lotteryness

\begin{tabular}{lcccc}
\hline \hline Dependent var.: & OPP & Synergy & ACAR & TCAR \\
\cline { 2 - 5 } & $(1)$ & $(2)$ & $(3)$ & $(4)$ \\
\hline RLIDX & 29.472 & -2.602 & -2.129 & 7.754 \\
& 4.71 & -3.00 & -2.30 & 2.28 \\
Firm Controls & Yes & Yes & Yes & Yes \\
Deal Controls & Yes & Yes & Yes & Yes \\
Adjusted $R^{2}$ & 0.115 & 0.089 & 0.068 & 0.124 \\
Number of observations & 2,971 & 3,046 & 3,070 & 3,070 \\
\hline \hline
\end{tabular}

Panel B: Lotteryness of the Combined Firm (Subsample Analysis)

\begin{tabular}{l|c|ccc|ccc}
\hline \hline \multirow{2}{*}{ Variable } & Baseline & \multicolumn{3}{|c}{ Large \& Non-Div. } & \multicolumn{3}{c}{ Large \& Corr. } \\
\cline { 3 - 8 } Estimates & Yes & No & Diff. & Yes & No & Diff. \\
\hline Synergy [-1,+1] & -2.400 & -5.176 & -1.344 & -3.832 & -2.832 & -2.292 & -0.540 \\
& -3.63 & -3.10 & -1.90 & -2.06 & -2.03 & -2.87 & -0.32 \\
& 3,336 & 984 & 2,352 & & 1,209 & 2,127 & \\
ACAR [-1,+1] & -3.392 & -6.678 & -2.269 & -4.409 & -5.692 & -2.031 & -3.661 \\
& -4.98 & -3.78 & -3.00 & -2.22 & -3.81 & -2.54 & -2.04 \\
& 3,360 & 989 & 2,371 & & 1,215 & 2,145 & \\
\hline \hline
\end{tabular}




\section{TABLE VIII}

\section{Gambling propensity, managerial discretion, and gambling for resurrection}

This table presents results for OLS regressions of acquiror announcement returns (ACAR $[-1,+1])$ and Synergy $[-1,+1]$ on our lottery measures LIDX and control variables. Bidder and target cumulative abnormal announcement returns are computed using the $[-1,+1]$ event window and a market model estimated over days [-280,-31]. Synergy [-1,+1] is defined following Bradley, Desai, and Kim (1988) as weighted sum (by market capitalization) of the bidder and target cumulative abnormal announcement returns. The lottery index LIDX measures the similarity of the stock of the target with salient features of attractive gambles. LIDX increases in the attractiveness of the target as a gamble. The constituents of LIDX are the price of the target's stock (Price), expected idiosyncratic skewness (EISKEW), and idiosyncratic volatility (IVOLA), all measured at the end of the second month prior to the month of the announcement. The baseline regression is model (5) from Tables IV and V (Panel A). In Panel A, the baseline regression is rerun for 6 different subsamples: (i) high (low) CPRATIO (the ratio of Catholic to Protestant population in the county where the acquiror headquarter is located), defined as CPRATIO values in (below) the top terzile, (ii) negative (positive) CFNAI (the Chicago Fed National Activity Index), (iii) above (below) median age of the CEO of the acquiring firm. In Panel B, the baseline regression is rerun for 6 different subsamples: (i) above (below) median acquiror management entrenchment measured by the GIM-Index, (ii) above (below) median percentage ownership of the bidder firm's CEO, (iii) above (below) median product market competition (PM Comp.) measured by the Herfindahl index (sum of squared market shares measured in sales) in the acquiror's 3-digit SIC code industry. In Panel C, the baseline regression is rerun for 6 different subsamples: (i) above or below median RET12 (the cumulative return of the bidder's stock calculated over months $t-13$ to $t-2$ for a takeover announcement in month $t$ ), (ii) above or below median DIFF52 (the ratio of the bidder's stock price at the end of month $t-2$ and the 52 -week high over the months $t-13$ to $t-2$ minus one), (iii) negative or positive net income in the last fiscal year before the takeover announcement. The table reports the coefficient estimates of LIDX and its t-statistic as well as the number of observations in small font size below the estimates. The table also reports the difference between the coefficients on LIDX in the two subsamples and below the t-statistic from a Wald-test of equality of coefficients in small

font size. See Appendix Table A.1 for a detailed overview of variable definitions. Standard errors are clustered by announcement month. 


\section{TABLE VIII (Continued)}

Gambling propensity, managerial discretion, and gambling for resurrection

Panel A: Measures of Gambling Propensity

\begin{tabular}{l|c|ccc|ccc|ccc}
\hline \hline & Baseline & \multicolumn{3}{|c}{ CPRATIO } & \multicolumn{4}{c}{ CFNAI } & \multicolumn{4}{c}{ CEO Age } \\
\cline { 3 - 10 } Variable & Estimates & High & Low & Diff. & Neg. & Pos. & Diff. & Young & Old & Diff. \\
\hline Synergy [-1,+1] & -2.400 & -3.593 & -0.909 & -2.684 & -3.361 & -1.654 & -1.707 & -5.837 & 0.353 & -6.190 \\
& -3.63 & -3.73 & -0.87 & -1.98 & -3.08 & -2.03 & -1.89 & -3.21 & 0.19 & -2.34 \\
& 3,336 & 1,780 & 1,345 & & 1,196 & 2,140 & & 474 & 402 & \\
ACAR $[-1,+1]$ & -3.392 & -4.605 & -1.309 & -3.296 & -4.350 & -2.704 & -1.646 & -6.885 & 1.604 & -8.489 \\
& -4.98 & -4.59 & -1.23 & -2.27 & -4.26 & -2.96 & -1.86 & -3.61 & 0.87 & -3.15 \\
& 3,360 & 1,791 & 1,357 & & 1,203 & 2,157 & & 474 & 404 & \\
\hline \hline
\end{tabular}

Panel B: Measures of Managerial Discretion

\begin{tabular}{l|c|ccc|ccc|ccc}
\hline \hline \multirow{2}{*}{ Variable } & Baseline & \multicolumn{3}{|c}{ GIM Index } & \multicolumn{3}{c}{ CEO Ownership } & \multicolumn{3}{c}{ PM Competition } \\
\cline { 3 - 10 } Synergy [-1,+1] & Estimates & High & Low & Diff. & High & Low & Diff. & Weak & Strong & Diff. \\
& -2.400 & -5.650 & -1.939 & -3.711 & -6.418 & -0.708 & -5.710 & -4.154 & -0.520 & -3.634 \\
& -3.63 & -3.77 & -1.79 & -2.01 & -4.67 & -0.64 & -3.04 & -4.14 & -0.53 & -2.48 \\
& 3,336 & 584 & 724 & & 650 & 1,100 & & 1,805 & 1,329 & \\
ACAR $[-1,+1]$ & -3.392 & -6.494 & -2.242 & -4.252 & -6.437 & -0.794 & -5.643 & -4.994 & -1.620 & -3.374 \\
& -4.98 & -3.98 & -1.83 & -2.06 & -4.58 & -0.67 & -2.99 & -5.15 & -1.49 & -2.30 \\
& 3,360 & 590 & 729 & & 653 & 1,112 & & 1,812 & 1,344 & \\
\hline \hline
\end{tabular}

Panel C: Gambling for Resurrection

\begin{tabular}{l|c|ccc|ccc|ccc}
\hline \hline & Baseline & \multicolumn{3}{|c}{ RET12 } & \multicolumn{3}{c}{ DIFF52 } & \multicolumn{3}{c}{ Net Income } \\
\cline { 3 - 10 } Variable & Estimates & High & Low & Diff. & Large & Small & Diff. & Neg. & Pos. & Diff. \\
\hline Synergy [-1,+1] & -2.400 & -4.109 & -0.979 & -3.130 & -4.589 & -0.890 & -3.699 & -7.157 & -1.991 & -5.166 \\
& -3.63 & -3.83 & -0.94 & -1.96 & -4.57 & -1.00 & -2.82 & -2.31 & -2.80 & -1.71 \\
& 3,336 & 1,516 & 1,530 & & 1,555 & 1,571 & & 465 & 2,871 & \\
ACAR [-1,+1] & -3.392 & -5.899 & -1.129 & -4.770 & -5.371 & -1.747 & -3.624 & -9.096 & -1.961 & -7.135 \\
& -4.98 & -5.16 & -1.00 & -2.76 & -5.12 & -1.80 & -2.51 & -2.90 & -2.67 & -2.15 \\
& 3,360 & 1,526 & 1,544 & & 1,565 & 1,585 & & 468 & 2,892 & \\
\hline \hline
\end{tabular}




\section{TABLE IX}

\section{Determinants of Acquisition Lotteryness}

This table presents results for OLS regressions of the lottery measure LIDX on measures of managerial gambling propensity and discretion, as well as control variables. The lottery index LIDX measures the similarity of the stock of the target with salient features of attractive gambles. LIDX increases in the attractiveness of the target as a gamble. If an acquiror undertakes more than one acquisition in one of our sample years the average LIDX of all targets is used as dependent variable. The constituents of LIDX are the price of the target's stock (Price), expected idiosyncratic skewness (EISKEW), and idiosyncratic volatility (IVOLA), all measured at the end of the second month prior to the month of the announcement. The variables on managerial gambling propensity and discretion have been previously defined in Table VII. Control variables are the full set of variables used in Table III to V, specification (5). The table reports coefficient estimates and the t-statistic in small font below the coefficient estimates. See Appendix Table A.1 for a detailed overview of variable definitions. Standard errors are clustered at the acquiror level.

\begin{tabular}{|c|c|c|c|c|c|c|c|c|c|}
\hline \multirow[t]{2}{*}{ Dep. var.: } & \multicolumn{9}{|c|}{$\begin{array}{c}\text { LIDX } \\
\end{array}$} \\
\hline & (1) & $(2)$ & (3) & (4) & $(5)$ & (6) & (7) & (8) & (9) \\
\hline \multirow[t]{2}{*}{ CP-ratio (high) } & 0.018 & & & & & & & & \\
\hline & 2.73 & & & & & & & & \\
\hline \multirow[t]{2}{*}{ CFNAI (neg.) } & & 0.014 & & & & & & & \\
\hline & & 2.21 & & & & & & & \\
\hline \multirow[t]{2}{*}{ CEO age (young) } & & & 0.010 & & & & & & \\
\hline & & & 1.08 & & & & & & \\
\hline \multirow[t]{2}{*}{ GIM-index (high) } & & & & -0.024 & & & & & \\
\hline & & & & -2.48 & & & & & \\
\hline \multirow[t]{2}{*}{ CEO ownership (high) } & & & & & 0.023 & & & & \\
\hline & & & & & 2.98 & & & & \\
\hline \multirow[t]{2}{*}{ PM Comp. (weak) } & & & & & & 0.022 & & & \\
\hline & & & & & & 2.41 & & & \\
\hline \multirow[t]{2}{*}{ Return last 12 months (low) } & & & & & & & 0.018 & & \\
\hline & & & & & & & 2.78 & & \\
\hline \multirow[t]{2}{*}{ Diff to 52-week high (large) } & & & & & & & & 0.044 & \\
\hline & & & & & & & & 7.08 & \\
\hline \multirow[t]{2}{*}{ Net income (neg.) } & & & & & & & & & 0.109 \\
\hline & & & & & & & & & 9.94 \\
\hline All Controls & Yes & Yes & Yes & Yes & Yes & Yes & Yes & Yes & Yes \\
\hline Adjusted $R^{2}$ & 0.600 & 0.596 & 0.602 & 0.607 & 0.606 & 0.605 & 0.599 & 0.603 & 0.608 \\
\hline Number of observations & 2,894 & 3,089 & 1,478 & 1,159 & 2,898 & 1,555 & 2,794 & 2,884 & 3,089 \\
\hline
\end{tabular}




\section{TABLE X}

\section{Determinants of Takeover Likelihood}

This table presents results for Probit acquisition likelihood regressions on a sample of target and non-target firms from the Compustat universe between 1987 and 2008. The dependent variable is one for a firm in the last year it appears in the Compustat database if the reason for deletion from the file is given by Compustat to be "Acquisition or Merger" (DLRSN code =1). The main explanatory variable is the lottery index LIDX, which measures the similarity of a firm's stock with salient features of attractive gambles. LIDX increases in the attractiveness of the firm as a gamble. The constituents of LIDX are the price of the target's stock (Price), expected idiosyncratic skewness (EISKEW), and idiosyncratic volatility (IVOLA), all measured at the end of the fiscal year. The other control variables follow Palepu (1986) and Ambrose and Megginson (1992). Return on equity is the three year average of net income over shareholder's equity. The Growth-Resource Dummy is one if the firm is either low Sales Growth/high Liquid Assets/low Leverage, or high Sales Growth/low Liquid Assets/high Leverage, where high and low categories are assigned according to the sample median. Sales Growth is the three year average of the year-to-year change in sales. Liquid Assets is the three year average of cash and equivalents plus receivables over total assets. Leverage is defined as three year average of total long-term debt over the book value of equity. Market-to-book is the market value of equity to the book value of equity. PE Ratio is the ratio of the share price at calender year end divided by earnings per share. Size is measured by total assets and Tangible Assets are defined as the book value of property plant and equipment over book assets. Industry Takeover Activity is a dummy equal to one if there was at least one merger in the same four digit SIC code industry in the prior year. Industry matching includes only firms in four digit SIC code industries for which there is at least one takeover in the year. Industry and size matching includes only firms in the four digit SIC code industry-size decile combination for which there is at least one takeover in the year. Financial firms (SIC one digit code of 6) are excluded. The table reports coefficient estimates and the z-statistic in small font below the coefficient estimates. Standard errors are clustered at the firm level. 


\section{TABLE X (Continued)}

\section{Determinants of Takeover Likelihood}

\begin{tabular}{|c|c|c|c|c|c|c|}
\hline \multirow[t]{5}{*}{ Dep. var.: } & \multicolumn{6}{|c|}{ Indicator: Firm taken over in current year } \\
\hline & \multirow{3}{*}{$\begin{array}{c}\text { Full } \\
\text { Sample }\end{array}$} & \multirow{3}{*}{$\begin{array}{c}\text { Full } \\
\text { Sample }\end{array}$} & \multicolumn{4}{|c|}{ Match by... } \\
\hline & & & Industry & Industry & Industry & Industry \\
\hline & & & Only & Only & \& Size & \& Size \\
\hline & (1) & $(2)$ & $(3)$ & $(4)$ & $(5)$ & (6) \\
\hline \multirow[t]{2}{*}{ LIDX } & 0.463 & 0.429 & 0.423 & 0.396 & 0.345 & 0.302 \\
\hline & 10.20 & 8.88 & 8.83 & 8.07 & 6.88 & 5.91 \\
\hline \multirow[t]{2}{*}{ Return on equity } & -0.220 & -0.284 & -0.160 & -0.205 & -0.055 & -0.157 \\
\hline & -3.42 & -4.20 & -2.42 & -3.03 & -0.79 & -2.19 \\
\hline \multirow[t]{2}{*}{ Growth-Resource Dummy } & 0.026 & 0.006 & 0.011 & 0.001 & 0.013 & 0.005 \\
\hline & 1.37 & 0.33 & 0.58 & 0.08 & 0.61 & 0.22 \\
\hline \multirow[t]{2}{*}{ Sales Growth } & 0.043 & -0.053 & -0.097 & -0.126 & -0.170 & -0.185 \\
\hline & 0.95 & -1.14 & -2.12 & -2.69 & -3.46 & -3.64 \\
\hline \multirow[t]{2}{*}{ Liquid Assets } & 0.196 & 0.116 & 0.170 & 0.079 & -0.005 & -0.046 \\
\hline & 3.34 & 1.74 & 2.81 & 1.18 & -0.08 & -0.66 \\
\hline \multirow[t]{2}{*}{ Leverage } & 0.082 & 0.084 & 0.093 & 0.086 & 0.107 & 0.098 \\
\hline & 11.42 & 11.13 & 12.23 & 11.00 & 12.89 & 11.48 \\
\hline \multirow[t]{2}{*}{ Market-to-book } & -0.004 & -0.012 & -0.010 & -0.012 & -0.011 & -0.009 \\
\hline & -0.95 & -2.86 & -2.59 & -2.90 & -2.53 & -2.22 \\
\hline \multirow[t]{2}{*}{ PE Ratio } & 0.000 & 0.000 & 0.000 & 0.000 & 0.000 & 0.000 \\
\hline & 0.29 & 0.16 & 0.23 & 0.16 & -0.15 & -0.20 \\
\hline \multirow[t]{2}{*}{ Size } & -0.009 & -0.010 & -0.009 & -0.011 & -0.011 & -0.012 \\
\hline & -2.21 & -2.49 & -2.20 & -2.49 & -2.36 & -2.65 \\
\hline \multirow[t]{2}{*}{ Tangible Assets } & -0.014 & -0.056 & 0.007 & -0.020 & -0.067 & -0.030 \\
\hline & -0.48 & -1.57 & 0.24 & -0.54 & -2.21 & -0.78 \\
\hline \multirow[t]{2}{*}{ Industry Takeover Activity } & 0.205 & 0.293 & -0.016 & 0.013 & -0.044 & -0.017 \\
\hline & 8.88 & 10.67 & -0.55 & 0.44 & -1.38 & -0.52 \\
\hline Year Dummies & No & Yes & Yes & Yes & Yes & Yes \\
\hline Industry Dummies & No & Yes & No & Yes & No & Yes \\
\hline Pseudo $R^{2}$ & 0.023 & 0.054 & 0.039 & 0.049 & 0.051 & 0.065 \\
\hline Number of observations & 53,746 & 53,717 & 47,359 & 47,349 & 33,817 & 33,806 \\
\hline
\end{tabular}




\section{TABLE XI}

\section{Lottery Acquisitions and Synergies}

This table presents results for two-step Heckman regressions with projected synergies and acquiror announcement returns (ACAR $[-1,+1]$ ) as dependent variable. Columns 1 and 4 present the first stage Probit regressions with a dummy variable for disclosure of synergy forecasts as dependent variable. Bidder cumulative abnormal announcement returns are computed using the $[-1,+1]$ event window and a market model estimated over days [-280,-31]. Projected synergies are defined following Bernile and Bauguess (2010) as present value of the merger-related incremental cash flows projected by management scaled by the sum of acquiror and target market capitalization at the last fiscal year before the acquisition announcement. The lottery index LIDX measures the similarity of the stock of the target with salient features of attractive gambles. LIDX increases in the attractiveness of the target as a gamble. The constituents of LIDX are the price of the target's stock (Price), expected idiosyncratic skewness (EISKEW), and idiosyncratic volatility (IVOLA), all measured at the end of the second month prior to the month of the announcement. Control variables are the same acquiror, target, and deal characteristics used in Table III to V. The t-statistics for the coefficient estimates are reported in small font size below the estimates. See Appendix Table A.1 for a detailed overview of variable definitions. Standard errors are clustered by announcement month. 
TABLE XI (Continued)

Lottery Acquisitions and Synergies

\begin{tabular}{|c|c|c|c|c|c|c|}
\hline \multirow[t]{2}{*}{ Dep. var.: } & $\begin{array}{l}\text { Disclose } \\
\text { (Probit) }\end{array}$ & $\begin{array}{c}\text { Synergies } \\
\text { (Heckit) }\end{array}$ & $\begin{array}{c}\text { ACAR } \\
\text { (Heckit) }\end{array}$ & $\begin{array}{l}\text { Disclose } \\
\text { (Probit) }\end{array}$ & $\begin{array}{c}\text { Synergies } \\
\text { (Heckit) }\end{array}$ & $\begin{array}{c}\text { ACAR } \\
\text { (Heckit) }\end{array}$ \\
\hline & $(1)$ & $(2)$ & $(3)$ & $(4)$ & $(5)$ & $(6)$ \\
\hline \multirow[t]{2}{*}{ LIDX } & -1.297 & 0.114 & -10.946 & -0.680 & 0.102 & -8.029 \\
\hline & -5.53 & 1.69 & -1.99 & -2.84 & 2.38 & -2.22 \\
\hline \multirow[t]{2}{*}{ Projected Synergies } & & & 17.169 & & & 16.486 \\
\hline & & & 3.30 & & & 3.16 \\
\hline \multirow[t]{2}{*}{ LIDX $\times$ Projected Synergies } & & & -20.082 & & & -20.181 \\
\hline & & & -2.24 & & & -2.24 \\
\hline \multirow[t]{2}{*}{ Acquiror ROA } & -0.191 & -0.014 & 1.224 & 0.189 & -0.044 & 0.611 \\
\hline & -0.64 & -0.27 & 0.31 & 0.59 & -0.85 & 0.15 \\
\hline \multirow[t]{2}{*}{ Acquiror BM Ratio } & 0.048 & -0.004 & 1.127 & 0.070 & -0.005 & 0.981 \\
\hline & 1.08 & -0.69 & 2.15 & 1.50 & -0.76 & 1.85 \\
\hline \multirow[t]{2}{*}{ Acquiror MCAP } & -0.202 & -0.029 & -0.280 & -0.181 & -0.029 & -0.122 \\
\hline & -5.69 & -2.75 & -0.32 & -5.12 & -3.30 & -0.17 \\
\hline \multirow[t]{2}{*}{ Target ROA } & -0.147 & -0.016 & -6.664 & -0.155 & -0.041 & -7.304 \\
\hline & -0.71 & -0.37 & -2.06 & -0.75 & -0.96 & -2.26 \\
\hline \multirow[t]{2}{*}{ Target BM Ratio } & 0.387 & 0.047 & 2.139 & 0.414 & 0.036 & 1.738 \\
\hline & 5.71 & 2.38 & 1.34 & 5.84 & 1.96 & 1.18 \\
\hline \multirow[t]{2}{*}{ Target MCAP } & 0.439 & 0.015 & 1.026 & 0.477 & 0.011 & 0.930 \\
\hline & 9.67 & 0.76 & 0.63 & 10.86 & 0.59 & 0.61 \\
\hline \multirow[t]{2}{*}{ Relative Size } & -0.056 & 0.025 & -1.063 & -0.047 & 0.024 & -0.920 \\
\hline & -1.33 & 3.98 & -2.02 & -1.11 & 3.94 & -1.87 \\
\hline \multirow[t]{2}{*}{ Cash } & & & & -0.484 & 0.039 & -0.670 \\
\hline & & & & -4.03 & 1.50 & -0.33 \\
\hline \multirow[t]{2}{*}{ Stock } & & & & -0.106 & 0.006 & -0.428 \\
\hline & & & & -1.24 & 0.59 & -0.50 \\
\hline \multirow[t]{2}{*}{ Tender } & & & & -0.124 & 0.011 & 0.948 \\
\hline & & & & -1.04 & 0.67 & 0.71 \\
\hline \multirow[t]{2}{*}{ Hostile } & & & & -0.453 & 0.025 & -0.749 \\
\hline & & & & -1.83 & 0.64 & -0.24 \\
\hline \multirow[t]{2}{*}{ Conglomerate } & & & & -0.100 & 0.022 & -0.331 \\
\hline & & & & -1.27 & 2.14 & -0.40 \\
\hline \multirow[t]{2}{*}{ Competed } & & & & -0.240 & 0.058 & -3.815 \\
\hline & & & & -1.75 & 2.85 & -2.31 \\
\hline \multirow[t]{2}{*}{ New Economy } & & & & -0.447 & -0.023 & -3.621 \\
\hline & & & & -3.95 & -0.96 & -1.95 \\
\hline \multirow[t]{2}{*}{$\log$ (Number of Deals) } & & & & 0.095 & -0.006 & -0.076 \\
\hline & & & & 2.85 & -1.16 & -0.18 \\
\hline Number of observations & 2,180 & 2,180 & 2,180 & 2,179 & 2,179 & 2,179 \\
\hline Number of censored observations & & 1,620 & 1,620 & & 1,619 & 1,619 \\
\hline Number of uncensored observations & & 560 & 560 & & 560 & 560 \\
\hline
\end{tabular}


FIGURE 1

The Impact of Gambling Attitudes on Synergies and Acquiror Announcement Returns

This figure shows the impact of a one standard deviation change in the lottery index LIDX on synergies and acquiror announcement returns for the subsamples in Table VIII. For every test, acquisitions are grouped into subgroups in which the likelihood of gambling is high or low, respectively. The figure shows the implied change in synergies (Panel A) and acquiror announcement returns (Panel B), as well as the difference between the two. Changes are calculated by multiplying the LIDX standard deviation by the respective coefficient from the regressions in Table VIII. Bidder cumulative abnormal announcement returns are computed using the $[-1,+1]$ event window and a market model estimated over days [-280,-31]. Synergies are computed using the $[-1,+1]$ event window following Bradley, Desai, and Kim (1988) as weighted sum (by market capitalization) of the bidder and target cumulative abnormal announcement returns.

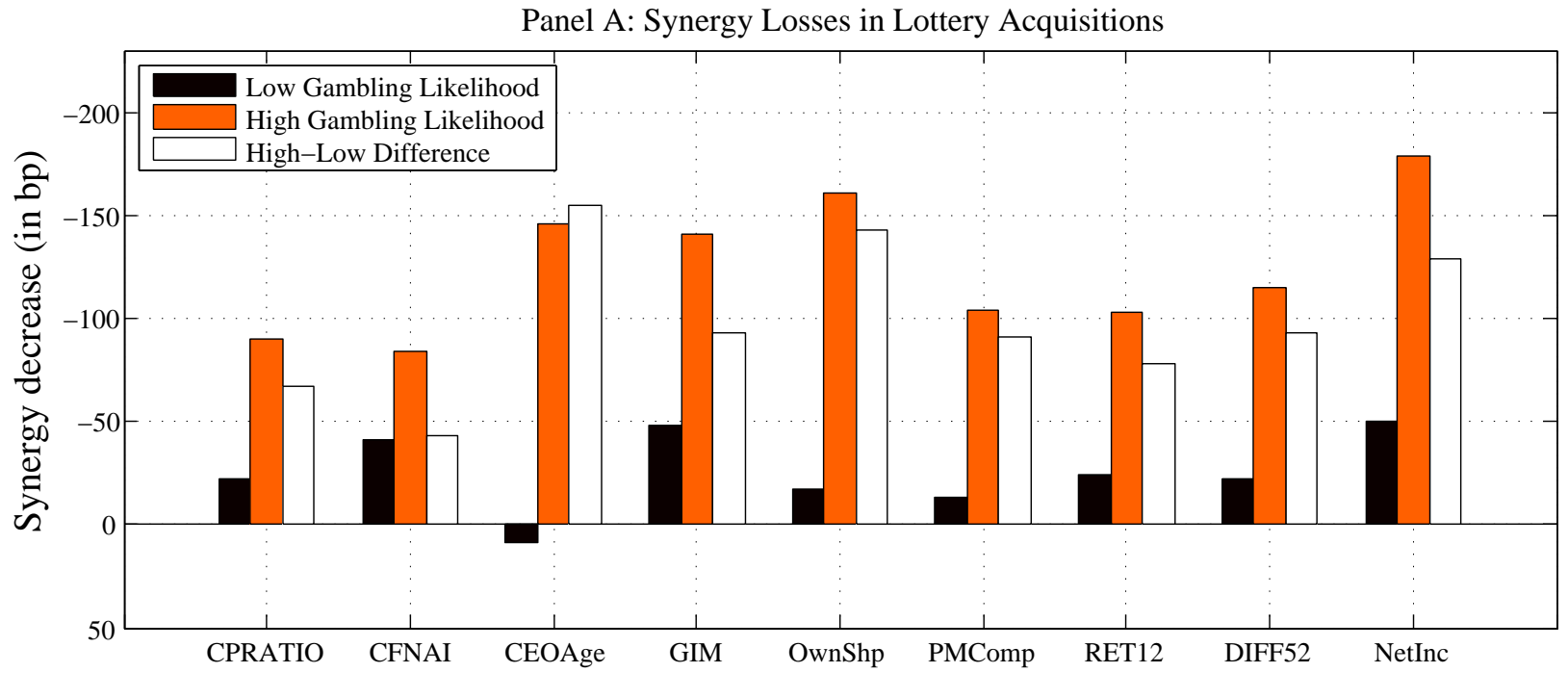

Panel B: Losses to Acquirer in Lottery Acquisitions around Announcement Date

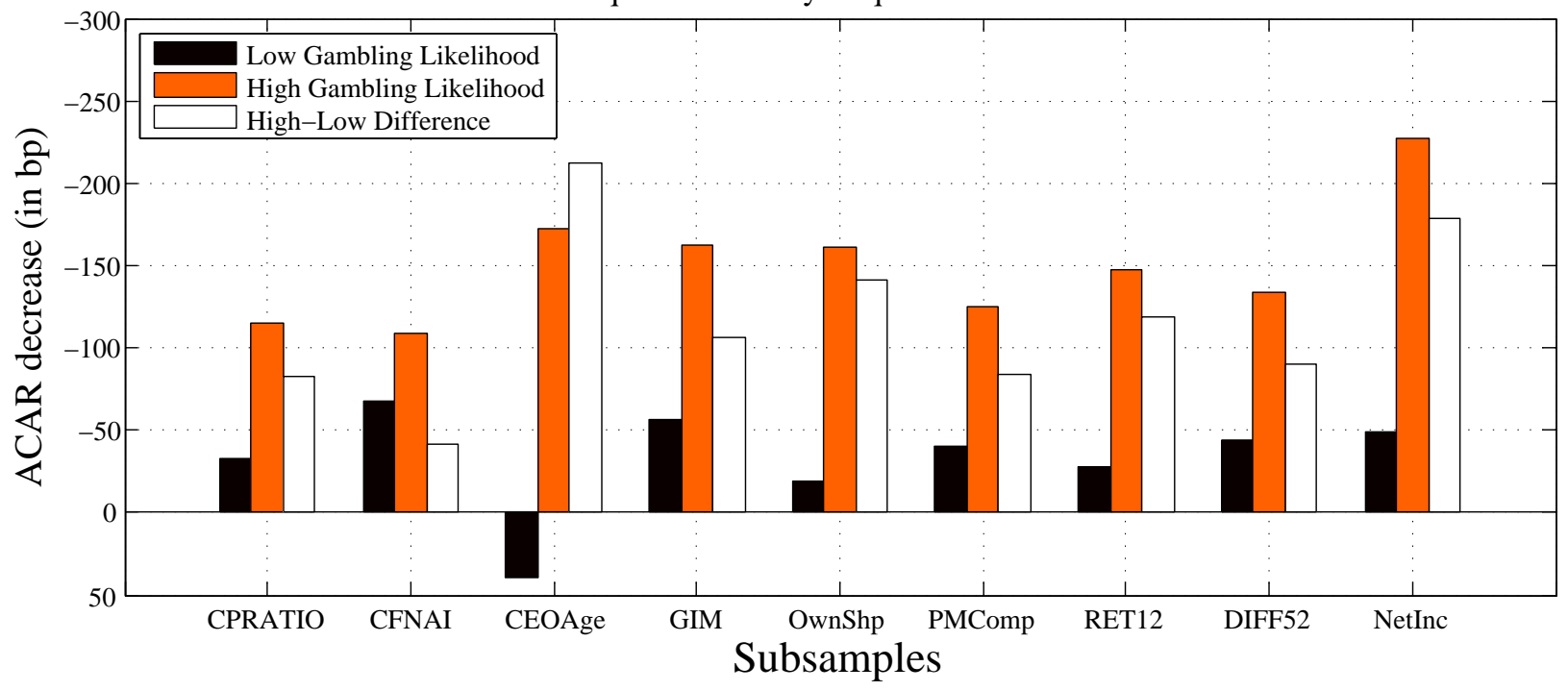




\section{Appendix}

\section{TABLE A.I}

\section{Variable Definitions and Sources}

This table briefly defines the main variables used in the empirical analysis. The data sources are: (i) ARDA: Association of Religion Data Archives, (ii) Compustat, (iii) CRSP: Center for Research on Security Prices, (iv) Andrew Metrick's website: www.som.yale.edu/faculty/am859/data.html, (v) Chicago Fed, (vi) Execucomp. Table II reports the summary statistics for all these variables.

\begin{tabular}{|c|c|c|}
\hline Variable name & Description & Source \\
\hline \multicolumn{3}{|c|}{ Lottery variables } \\
\hline LIDX & $\begin{array}{l}\text { Stocks are assigned to vigintiles (semi-deciles) by price, idiosyncratic } \\
\text { volatility, and expected idiosyncratic skewness (where } 20 \text { is the lowest } \\
\text { price group and the highest volatility and skewness groups). The price, } \\
\text { volatility and skewness vigintile assignments are added for each target } \\
\text { to produce a score ranging from } 3 \text { to } 60 \text {, which is then scaled to range } \\
\text { from } 0 \text { to } 1 \text { using (Score- } 3) /(60-3) \text {. }\end{array}$ & CRSP \\
\hline EISKEW & $\begin{array}{l}\text { Expected idiosyncratic skewness estimated following Boyer, Mitton, } \\
\text { and Vorkink (2009). For an announcement in month } t \text {, we calculate } \\
\text { EISKEW for the four year period ending in month } t-2 \text {. }\end{array}$ & CRSP \\
\hline IVOLA & $\begin{array}{l}\text { Idiosyncratic volatility (standard deviation) of regression residual using } \\
\text { the Fama and French (1993) three-factor model. Residuals are estimated } \\
\text { using daily data over a four year period prior ending in month } t-2 \text { for } \\
\text { an announcement in month } t \text {. }\end{array}$ & CRSP \\
\hline Price & $\begin{array}{l}\text { Share price on the last trading day in month } t-2 \text { before the takeover } \\
\text { announcement in month } t \text {. }\end{array}$ & CRSP \\
\hline \multicolumn{3}{|c|}{ Acquiror and target characteristics } \\
\hline ROA & $\begin{array}{l}\text { Bidder (target) firm return on assets }(=\text { net income / total assets) from } \\
\text { the last fiscal year before the takeover announcement. }\end{array}$ & Compustat \\
\hline BM Ratio & $\begin{array}{l}\text { Ratio of book value of equity ( }=\text { stockholders' equity }+ \text { deferred taxes } \\
\text { and investment tax credit - redemption value of preferred stock) to mar- } \\
\text { ket value of equity (MCAP) the last fiscal year end before the takeover } \\
\text { announcement for the bidder (target) firm. }\end{array}$ & $\begin{array}{l}\text { CRSP, } \\
\text { Compustat }\end{array}$ \\
\hline MCAP & $\begin{array}{l}\text { Natural log of Price } * \text { Shares outstanding (in millions) at the last fiscal } \\
\text { year end before the takeover announcement for the bidder (target) firm. }\end{array}$ & CRSP \\
\hline Relative Size & $\begin{array}{l}\text { Transaction value over bidders market capitalization at the last fiscal } \\
\text { year end before the takeover announcement. }\end{array}$ & $\begin{array}{l}\text { SDC, } \\
\text { CRSP }\end{array}$ \\
\hline New Economy & $\begin{array}{l}1 \text { if the target is a new economy firm. Following Oyer and Scheafer } \\
\text { (2005) targets with SIC codes } 3570 \text { to } 3579,3663,3674,5045,5961 \text {, and } \\
7370 \text { to } 7379 \text { are defined as new economy firms. }\end{array}$ & SDC \\
\hline Z-Score & $\begin{array}{l}\text { Altman's }(1968) \text { z-score, as modified by MacKie-Mason }(1990) \text {, is de- } \\
\text { fined as }\left[3.3^{*} \text { (operating income before depreciation - depreciation and }\right. \\
\left.\text { amortization })+ \text { sales }+1.4^{*} \text { retained earnings }+1.2 * \text { working capital }\right] \\
\text { / total assets. }\end{array}$ & Compustat \\
\hline
\end{tabular}


TABLE A.I (Continued)

\section{Variable Definitions and Sources}

\begin{tabular}{|c|c|c|}
\hline Variable name & Description & Source \\
\hline \multicolumn{3}{|l|}{ Deal characteristics } \\
\hline $\mathrm{OPP}$ & $\begin{array}{l}\text { Offer price premium is defined as the bid price over the target's stock } \\
\text { price } 4 \text { weeks before the takeover announcement minus } 100 \% \text {. }\end{array}$ & $\mathrm{SDC}$ \\
\hline $\mathrm{A}(\mathrm{T}) \mathrm{CAR}[-1,+1]$ & $\begin{array}{l}\text { 3-day cumulative abnormal returns for the bidder (target) firm using } \\
\text { the market model. Market model parameters are estimated over days } \\
(-280,-31) \text {. }\end{array}$ & CRSP \\
\hline$\$ \mathrm{ACAR}[-1,+1]$ & $\begin{array}{l}\text { 3-day cumulative abnormal dollar returns for the bidder firm, de- } \\
\text { fined as ACAR }[-1,+1] * \text { AcquirorMCAP }[-2]-\text { Toehold } * \operatorname{TCAR}[-1,+1] * \\
\text { TargetMCAP }[-2] .\end{array}$ & $\mathrm{SDC}, \mathrm{CRSP}$ \\
\hline$\$ \mathrm{TCAR}[-1,+1]$ & $\begin{array}{l}\text { 3-day cumulative abnormal dollar returns for the target firm are defined } \\
\text { as TCAR }[-1,+1] * \text { TargetMCAP }[-2] \text {. }\end{array}$ & CRSP \\
\hline Synergy $[-1,+1]$ & $\begin{array}{l}\text { Percentage synergies calculated as }(\$ A C A R[-1,+1]+\$ \operatorname{TCAR}[-1,+1]) / \\
(\text { AcquirorMCAP }[-2]+(1-\text { Toehold }) * \text { TargetMCAP }[-2])\end{array}$ & $\mathrm{SDC}, \mathrm{CRSP}$ \\
\hline$\$$ Synergy $[-1,+1]$ & Dollar synergies are $\$$ ACAR $[-1,+1]+\$ \operatorname{TCAR}[-1,+1]$ & $\mathrm{SDC}, \mathrm{CRSP}$ \\
\hline Toehold & $\begin{array}{l}\text { Percent of shares held by the acquiror at the takeover announcement } \\
\text { date. }\end{array}$ & $\mathrm{SDC}$ \\
\hline Cash & 1 for deals financed with cash only. & $\mathrm{SDC}$ \\
\hline Stock & 1 for deals financed with stock only. & $\mathrm{SDC}$ \\
\hline Tender & 1 for tender offers. & $\mathrm{SDC}$ \\
\hline Hostile & 1 for hostile deals. & $\mathrm{SDC}$ \\
\hline Conglomerate & 1 where bidder and target are in a different 2-digit SIC code industry. & $\mathrm{SDC}$ \\
\hline Competed & 1 for deals with more than one bidder. & $\mathrm{SDC}$ \\
\hline $\log ($ Number of Deals $)$ & $\begin{array}{l}\text { Natural log of the number of sample transactions in the target's 2-digit } \\
\text { SIC code industry in the year of the takeover announcement. }\end{array}$ & $\mathrm{SDC}$ \\
\hline Completed & 1 for completed deals. & $\mathrm{SDC}$ \\
\hline \multicolumn{3}{|l|}{ Gambling propensity } \\
\hline CPRATIO & $\begin{array}{l}\text { Ratio of Catholic population to Protestant population in the county } \\
\text { where the acquiror headquarter is located. }\end{array}$ & $\begin{array}{l}\text { ARDA, US } \\
\text { Census }\end{array}$ \\
\hline CFNAI & $\begin{array}{l}\text { The CFNAI is a weighted average of } 85 \text { existing monthly indicators of } \\
\text { US economic activity. It is constructed to have an average value of zero } \\
\text { and a standard deviation of one. A positive index corresponds to growth } \\
\text { above trend and a negative index corresponds to growth below trend. }\end{array}$ & Chicago Fed \\
\hline CEO Age & Age of the bidder firm's CEO in the year of the takeover announcement & ExecuComp \\
\hline
\end{tabular}


TABLE A.I (Continued)

Variable Definitions and Sources

\begin{tabular}{|c|c|c|}
\hline Variable name & Description & Source \\
\hline \multicolumn{3}{|c|}{ Managerial discretion variables } \\
\hline GIM-Index & $\begin{array}{l}\text { Following Gompers, Ishii, and Metrick (2003), minimum } 1 \text { (low en- } \\
\text { trenchment), maximum } 19 \text { (high entrenchment). }\end{array}$ & $\begin{array}{l}\text { Andrew Met- } \\
\text { rick's website }\end{array}$ \\
\hline CEO Ownership & $\begin{array}{l}\text { Percentage stock ownership of the bidder firm's CEO in the year of the } \\
\text { takeover announcement }\end{array}$ & ExecuComp \\
\hline PM Competition & $\begin{array}{l}\text { Herfindahl index (sum of squared market shares measured in sales) in } \\
\text { the acquiror's major } 3 \text {-digit SIC code industry during the year prior to } \\
\text { the takeover announcement. }\end{array}$ & Compustat \\
\hline \multicolumn{3}{|c|}{ Variables indicating loss space } \\
\hline RET12 & $\begin{array}{l}\text { Cumulative return of the bidder's stock calculated over the months } t-13 \\
\text { to } t-2 \text { for an announcement in month } t \text {. }\end{array}$ & CRSP \\
\hline DIFF52 & $\begin{array}{l}\text { Difference of the current stock price of the acquiror to the } 52 \text {-week high, } \\
\text { scaled by the current stock price. The current stock price of the acquiror } \\
\text { is the stock price on the last trading day of month } t-2 \text { prior to the } \\
\text { takeover announcement month } t \text {. The } 52 \text {-week high is defined as the } \\
\text { highest share price during the } 12 \text { months ending on the last trading day } \\
\text { of month } t-2 \text {. }\end{array}$ & CRSP \\
\hline Net Income & $\begin{array}{l}\text { Net income of the bidder reported at last fiscal year end before the } \\
\text { announcement. }\end{array}$ & Compustat \\
\hline
\end{tabular}

